\title{
Recent advances in understanding the effects of lignin structural characteristics on enzymatic hydrolysis
}

Yufeng Yuan ${ }^{1}$, Bo Jiang ${ }^{1}$, Hui Chen ${ }^{1}$, Wenjuan Wu' ${ }^{1}$, Shufang Wu' ${ }^{1}$, Yongcan $\mathrm{Jin}^{1,3^{*}}$ and Huining Xiao ${ }^{2}$

\begin{abstract}
Enzymatic hydrolysis of lignocellulose for bioethanol production shows a great potential to remit the rapid consumption of fossil fuels, given the fact that lignocellulose feedstocks are abundant, cost-efficient, and renewable. Lignin results in low enzymatic saccharification by forming the steric hindrance, non-productive adsorption of cellulase onto lignin, and deactivating the cellulase. In general, the non-productive binding of cellulase on lignin is widely known as the major cause for inhibiting the enzymatic hydrolysis. Pretreatment is an effective way to remove lignin and improve the enzymatic digestibility of lignocellulose. Along with removing lignin, the pretreatment can modify the lignin structure, which significantly affects the non-productive adsorption of cellulase onto lignin. To relieve the inhibitory effect of lignin on enzymatic hydrolysis, enormous efforts have been made to elucidate the correlation of lignin structure with lignin-enzyme interactions but with different views. In addition, contrary to the traditional belief that lignin inhibits enzymatic hydrolysis, in recent years, the addition of water-soluble lignin such as lignosulfonate or low molecular-weight lignin exerts a positive effect on enzymatic hydrolysis, which gives a new insight into the lignin-enzyme interactions. For throwing light on their structure-interaction relationship during enzymatic hydrolysis, the effect of residual lignin in substrate and introduced lignin in hydrolysate on enzymatic hydrolysis are critically reviewed, aiming at realizing the targeted regulation of lignin structure for improving the saccharification of lignocellulose. The review is also focused on exploring the lignin-enzyme interactions to mitigate the negative impact of lignin and reducing the cost of enzymatic hydrolysis of lignocellulose.
\end{abstract}

Keywords: Lignocellulose, Enzymatic hydrolysis, Lignin, Cellulase, Interaction

\section{Background}

To reduce the negative impact of fossil fuels on energy and the environment, lignocellulose, as an abundant, green and renewable resource, has been widely used for bioethanol production to replace fossil fuels nowadays. Lignocellulose is rich in cellulose (40-50\%) along with hemicelluloses $(20-30 \%)$ and lignin (15-30\%) [1]. The linear cellulose and branched hemicelluloses are the

*Correspondence: jinyongcan@njfu.edu.cn

${ }^{3}$ Laboratory of Wood Chemistry, Nanjing Forestry University, 159 Longpan Rd, Nanjing 210037, China

Full list of author information is available at the end of the article main polysaccharides for green biofuels production via biorefinery technology $[2,3]$. However, the presence of lignin in the cell walls confers rigidity to the lignocellulose, which prevents the structural polysaccharides from degradation by microorganisms and enzymes (Fig. 1A). Lignin is an aromatic polymer with a three-dimensional network structure derived from three basic phenylpropanolic monomers, i.e., $p$-coumaryl, coniferyl, and sinapyl alcohols $[4,5]$. The three monolignols are incorporated into lignin biomacromolecule with the units of guaiacyl $(\mathrm{G})$, syringyl $(\mathrm{S})$ and $p$-hydroxyphenyl $(\mathrm{H})$ and linkages of $\beta-O-4, \beta-\beta, \alpha-O-4,4-O-5, \beta-5$, etc. (Fig. 1B). original author(s) and the source, provide a link to the Creative Commons licence, and indicate if changes were made. The images or other third party material in this article are included in the article's Creative Commons licence, unless indicated otherwise in a credit line to the material. If material is not included in the article's Creative Commons licence and your intended use is not permitted by statutory regulation or exceeds the permitted use, you will need to obtain permission directly from the copyright holder. To view a copy of this licence, visit http://creativecommons.org/licenses/by/4.0/. The Creative Commons Public Domain Dedication waiver (http://creativeco mmons.org/publicdomain/zero/1.0/) applies to the data made available in this article, unless otherwise stated in a credit line to the data. 

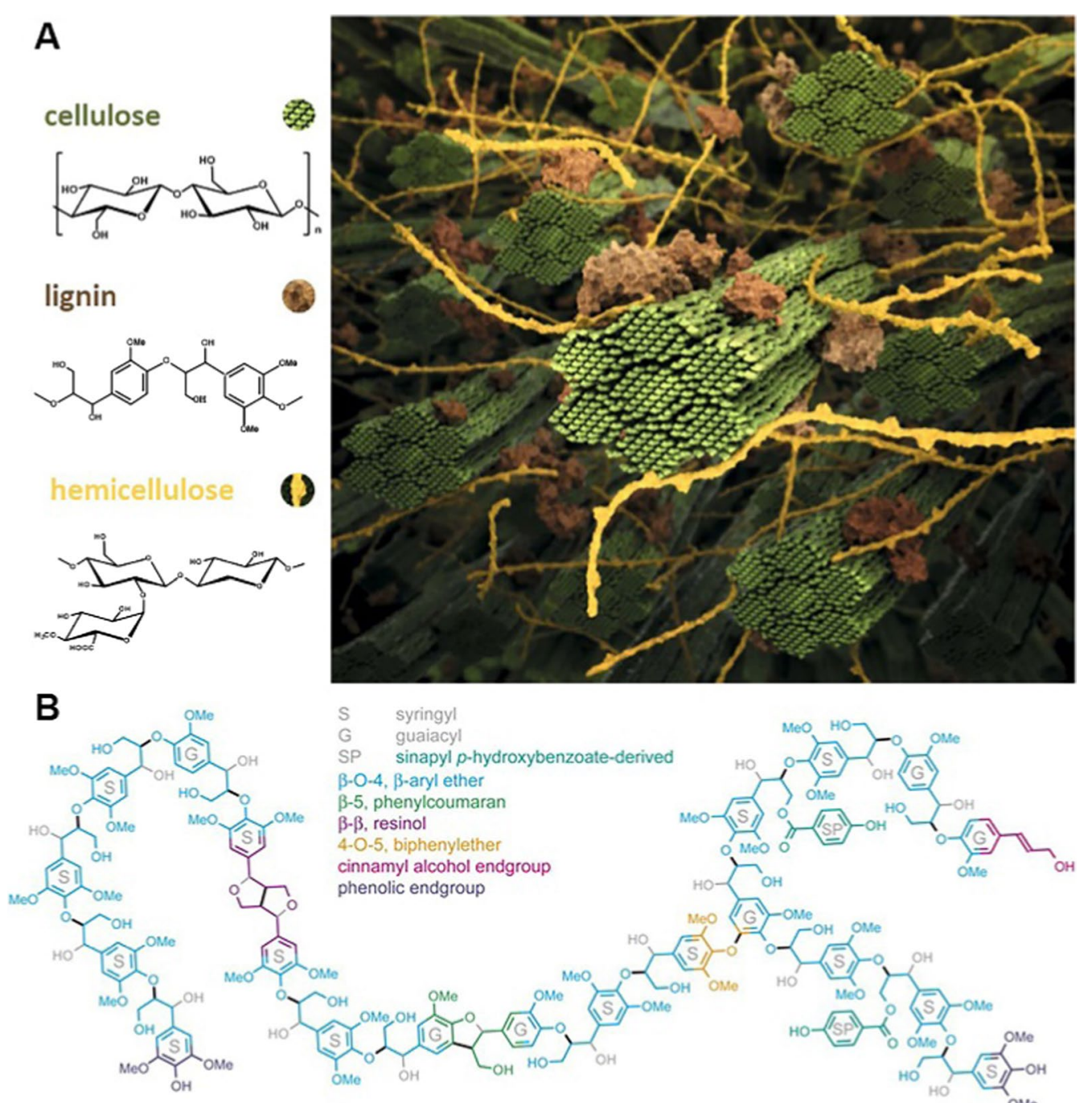

$\beta-0-4, \beta$-aryl ether

$\beta-5$, phenylcoumaran

$\beta \cdot \beta$, resinol

4-0-5, biphenylether

cinnamyl alcohol endgroup

phenolic endgroup

1 Structure of lignocellulosic biom

Fig. 1 Structure of lignocellulosic biomass and its components (A) [18] and representation of a lignin polymer from poplar, as predicted from NMR-based lignin analysis (B) [19]

In the process of enzymatic saccharification of lignocellulose, the non-productive adsorption of enzyme onto lignin caused by the hydrogen bonding, hydrophobic, and electrostatic interactions are thought to be the main reasons for the low saccharification efficiency of lignocellulose [6]. Steric hindrance of lignin macromolecule and lignin-based derivatives produced during the pretreatment process also shows negative effects on subsequent enzymatic hydrolysis. In addition, lignin is prone to co-precipitate with the enzyme protein, resulting in the irreversible adsorption of enzyme protein onto lignin. The protein folded structure is lost during the adsorption, thus decreasing the enzymatic activity $[7,8]$. To reduce or minimize the inhibitory effect of lignin, a number of measures have been employed, including the pretreatment, the use of additives and the genetic engineering of lignin biosynthesis. Pretreatment that removes part of the lignin and increases the accessible surface area of the substrate to cellulase is the most critical step to enhance the enzymatic saccharification efficiency [9]. The lignin-blocking additives (Tween 80 , bovine serum protein (BSA), polyethylene glycol (PEG) and the metal ions, etc.) have also been reported that can decrease the non-productive adsorption of cellulase onto lignin. For example, Tween 80 and BSA could mitigate the unproductive adsorption of cellulase on lignin by binding with lignin, thus improving the access of enzymes to cellulose $[10,11]$. Lin et al. [12] found that the addition of PEG could reduce the non-productive adsorption of cellulase onto lignin by forming the PEG-cellulase complex, which 
could disperse cellulase and avoid cellulase aggregation. Akimkulova et al. [13] suggested that $\mathrm{Mg}^{2+}$ weaken the non-productive adsorption of cellulase onto lignin driven by the electrostatic interaction and hydrogen-bonding. In addition, genetic manipulation of plants can also reduce the non-productive adsorption of cellulase onto lignin by reducing the lignin content or regulating the lignin biosynthesis $[14,15]$.

In recent years, several novel studies have found that water-soluble lignin (WSL), such as micromolecular lignin and lignosulfonate (LS), can promote enzymatic hydrolysis [16, 17], which gives a new insight in improving the enzymatic hydrolysis efficiency. However, the mechanism of enzymatic hydrolysis promoted by WSL is still unclear. At present, understanding the interaction between lignin and cellulase has become an important means to investigate the influence of lignin on enzymatic hydrolysis. The relationship of lignin with enzymatic hydrolysis efficiency, and the mechanism of interaction between lignin and cellulase are still worth illustrating further. Based on these, the recent progress on the effects of lignin content, distribution, structure and source on enzymatic hydrolysis, as well as the mechanism of lignin-cellulase interaction is critically reviewed in this article. Furthermore, this review also highlights the future perspective of the research focusing on the influence of lignin on enzyme protein activity by exploring the interactions between these two biomolecules.

\section{Effect of residual lignin on enzymatic hydrolysis Content of residual lignin in substrate}

The presence of lignin largely hinders the accessibility of enzymes to cellulose, which results in a very low enzymatic hydrolysis of the lignocellulose feedstock [20, 21]. Pretreatment is a key step in improving the efficiency of enzymatic hydrolysis by removing lignin and reducing the recalcitrance of lignocellulose [22-24]. Currently, the most important pretreatment methods for reducing the lignin content include the alkali, sulfite, organosolv, ionic liquids, and deep eutectic solvents pretreatments. The removal of lignin could significantly accelerate the enzymatic hydrolysis of lignocellulose. Alkali pretreatment, such as $\mathrm{NaOH}, \mathrm{Na}_{2} \mathrm{CO}_{3}$ and green liquor (GL), has been widely used to improve the digestibility of cellulose by removing the lignin. The ether linkages in lignin could be readily cleaved under alkaline and high-temperature conditions, resulting in an increased delignification, thus improving the accessibility of cellulase to cellulose. Sulfite pretreatment, including the sodium sulfite pretreatment and ammonium sulfite pretreatment, can also effectively remove lignin. During the sulfite pretreatment, the sulfite groups can attack the aliphatic side chains of lignin and replace the hydroxyl and/or ether functional groups. Consequently, lignin was largely sulfonated and became more hydrophilic. This change reduced the nonproductive adsorption of cellulase onto lignin and steric hindrance $[25,26]$. Excepting some organosolv pretreatments carried out under acidic conditions (Park et al. [27] showed that sulfuric acid-ethanol or magnesium chloride-ethanol rarely reduced lignin content of pitch pine. The original lignin content of pitch pine was $26.16 \%$. After treating by sulfuric acid-ethanol or magnesium chloride-ethanol, it was merely decreased to $23.78 \%$ and $25.78 \%$ ), most organosolv pretreatment also leads to a distinct improvement of enzymatic hydrolysis efficiency by extracting lignin from lignocellulosic materials, which also exposes more accessible surface area of cellulose and improves the enzymatic hydrolysis efficiency[28]. It is generally believed that the dissolution of lignin by ionic liquids is achieved by the basicity of the hydrogen bonds of anions and the acidity of the hydrogen bonds of cations, the $\pi-\pi$ interactions and hydrophobic interactions [29]. Deep eutectic solvent is a transparent mixture with a low freezing point obtained by the interaction between the hydrogen bond donor and the hydrogen bond acceptor [30]. The mechanism of deep eutectic solvent dissolving lignin is similar to that of ionic liquids, but it is more selective for extracting lignin rather than cellulose. Several common pretreatment methods for lignin removal and their effects on enzymatic hydrolysis are summarized in Table 1. Brienzo et al. [31] also investigated the enzymatic hydrolysis rate of sugarcane bagasse with different lignin content, and found that the samples with low lignin content generally showed a high glucose yield. Zhang et al. [32] used a novel film model composed of only lignin and cellulose to investigate the effect of lignin content on enzymatic hydrolysis. The results noticed that low lignin content in the film was beneficial for improving enzymatic hydrolysis rate. Hao et al. [33] prepared two lignin-rich residues (LRR-DA and LRR-NaOH) from corn stover through dilute acid (DA) pretreatment and dilute alkali $(\mathrm{NaOH})$ pretreatment. The LRR-DA exhibited a stronger inhibitory effect on enzymatic hydrolysis than LRR NaOH. This may be due to the higher surface lignin content of LRR-DA. Zhou et al.[34] found that the glucose yield of green liquor (GL)-sulfite pretreated sugarcane bagasse continued to increase within $72 \mathrm{~h}$, which was related to the low lignin content in the sugarcane bagasse. The above cases indicated that lignin content played a key role in the enzymatic hydrolysis and lignin content was negatively correlated with enzymatic hydrolysis efficiency.

In addition, genetic engineering to reduce the content of lignin has been shown to increase the efficiency of enzymatic hydrolysis. The rigid and compact structure of plant cell walls contributes to the lignocellulose 
Table 1 Several common pretreatment methods for lignin removal and their effects on enzymatic hydrolysis

\begin{tabular}{|c|c|c|c|c|c|}
\hline Substrate & Pretreatment & Enzymatic hydrolysis & $\begin{array}{l}\text { Lignin } \\
\text { removal/\% }\end{array}$ & Result & Refs. \\
\hline Wheat straw & $2 \% \mathrm{NaOH}, 80^{\circ} \mathrm{C}$, and $2 \mathrm{~h}$ & $\begin{array}{l}10 \%, 150 \mathrm{rpm}, 50^{\circ} \mathrm{C}, 72 \mathrm{~h} \text {, and } \\
\mathrm{pH}=4.8\end{array}$ & 71.8 & $\begin{array}{l}\text { Increasing the hydrolysis yield by } \\
32.4 \%\end{array}$ & [39] \\
\hline Corn stover & $\begin{array}{l}\mathrm{NaOH}+\mathrm{Na}_{2} \mathrm{~S}, 8 \% \text { total titratable } \\
\text { alkali, } 40 \% \text { sulfidity, } 140{ }^{\circ} \mathrm{C} \text {, and } 1 \mathrm{~h}\end{array}$ & $5 \%, 180 \mathrm{rpm}, 50^{\circ} \mathrm{C}, 48 \mathrm{~h}$, and $\mathrm{pH}=4.8$ & 45.0 & $\begin{array}{l}\text { The original polysaccharides conver- } \\
\text { sion: } 70.0 \%\end{array}$ & [40] \\
\hline Barley straw & $2 \% \mathrm{NaOH}, 105^{\circ} \mathrm{C}$, and $10 \mathrm{~min}$ & $1 \%, 180 \mathrm{rpm}, 50^{\circ} \mathrm{C}$, and $\mathrm{pH}=4.8$ & 84.8 & The reducing sugar yield: $86.5 \%$ & [41] \\
\hline Corncob & $\begin{array}{l}12 \% \text { sodium sulfite, } 160^{\circ} \mathrm{C}, 20 \mathrm{~min} \\
\text { and } \mathrm{pH}=7\end{array}$ & $2 \%, 95 \mathrm{rpm}, 50^{\circ} \mathrm{C}, 48 \mathrm{~h}$, and $\mathrm{pH}=4.8$ & 77.4 & $\begin{array}{l}\text { Increasing the glucose yield by } \\
20.1 \%\end{array}$ & {$[25]$} \\
\hline Wheat straw & $\begin{array}{l}20 \% \text { ammonium sulfite, } 4 \% \text { sodium } \\
\text { carbonate, } 180^{\circ} \mathrm{C} \text {, and } 1 \mathrm{~h}\end{array}$ & $2 \%, 50^{\circ} \mathrm{C}, 24 \mathrm{~h}$, and $\mathrm{pH}=5.0$ & 82.6 & $\begin{array}{l}99.9 \% \text { of glucan and } 88.0 \% \text { of xylan } \\
\text { were hydrolyzed }\end{array}$ & [26] \\
\hline Eucalyptus & $50 \%$ 2-propanol, $220^{\circ} \mathrm{C}$, and $2 \mathrm{~h}$ & $5 \%, 150 \mathrm{rpm}, 50^{\circ} \mathrm{C}, 72 \mathrm{~h}$, and $\mathrm{pH}=4.8$ & 81.3 & The glucose yields: $88.6 \%$ & {$[42]$} \\
\hline Wheat straw & $70 \%$ Glycerol, $220^{\circ} \mathrm{C}$, and $3 \mathrm{~h}$ & $2 \%, 150 \mathrm{rpm}, 50^{\circ} \mathrm{C}, 24 \mathrm{~h}$, and $\mathrm{pH}=4.8$ & 65.0 & $\begin{array}{l}\text { The reducing sugar conversion: } \\
90.0 \%\end{array}$ & {$[43]$} \\
\hline Eucalyptus & $\begin{array}{l}80 \% \text { tetrahydro-2-furanmethanol, } 1 \% \\
\mathrm{HCl}, 120-180^{\circ} \mathrm{C} \text {, and } 30 \mathrm{~min}\end{array}$ & $2 \%, 150 \mathrm{rpm}, 50^{\circ} \mathrm{C}, 72 \mathrm{~h}$, and $\mathrm{pH}=4.8$ & 94.0 & The hydrolysis conversion: $94.2 \%$ & [44] \\
\hline Corncob & $\begin{array}{l}\text { Choline chloride: Glycerol }(1: 2), 90^{\circ} \mathrm{C} \text {, } \\
\text { and } 24 \mathrm{~h}\end{array}$ & $\begin{array}{l}0.25 \%, 180 \mathrm{rpm}, 50^{\circ} \mathrm{C}, 72 \mathrm{~h} \text {, and } \\
\mathrm{pH}=4.8\end{array}$ & 87.6 & The glucose yield: $85.3 \%$ & [32] \\
\hline Eucalyptus & $\begin{array}{l}\text { Choline chloride: lactic acid (1:10), } \\
110^{\circ} \mathrm{C} \text {, and } 6 \mathrm{~h}\end{array}$ & $2 \%, 150 \mathrm{rpm}, 50^{\circ} \mathrm{C}, 72 \mathrm{~h}$, and $\mathrm{pH}=4.8$ & 80.0 & The glucose yield: $94.3 \%$ & {$[45]$} \\
\hline Corncob & $\begin{array}{l}\text { Choline chloride: imidazol (3:7), } \\
150^{\circ} \mathrm{C} \text {, and } 15 \mathrm{~h}\end{array}$ & $6 \%, 180 \mathrm{rpm}, 50^{\circ} \mathrm{C}, 80 \mathrm{~h}$, and $\mathrm{pH}=4.8$ & 88.0 & The glucose yield: $94.6 \%$ & [46] \\
\hline Corn stalk & $\begin{array}{l}\mathrm{N} \text {-methyl-2-pyrrolidonium chloride/ } \\
\mathrm{H}_{2} \mathrm{O}, 90^{\circ} \mathrm{C} \text {, and } 30 \text { min }\end{array}$ & $1 \%, 150 \mathrm{rpm}, 50^{\circ} \mathrm{C}, 72 \mathrm{~h}$, and $\mathrm{pH}=4.8$ & 85.9 & The glucose yield: $79.6 \%$ & {$[47]$} \\
\hline Switchgrass & $\begin{array}{l}\text { 1-Ethyl-3-methylimidazolium } \\
\text { acetate, } 160^{\circ} \mathrm{C} \text {, and } 3 \mathrm{~h}\end{array}$ & $\begin{array}{l}0.5 \%, 150 \mathrm{rpm}, 50^{\circ} \mathrm{C}, 24 \mathrm{~h} \text {, and } \\
\mathrm{pH}=4.8\end{array}$ & 69.2 & The glucose yield: $96.0 \%$ & {$[48]$} \\
\hline Rice straw & $\begin{array}{l}\text { 1-Buthyl-3-methylimidazolium } \\
\text { acetate, } 120^{\circ} \mathrm{C} \text {, and } 5 \mathrm{~h}\end{array}$ & $3 \%, 100 \mathrm{rpm}, 45^{\circ} \mathrm{C}, 72 \mathrm{~h}$, and $\mathrm{pH}=4.8$ & 41.4 & The glucose yield: $95.9 \%$ & [49] \\
\hline
\end{tabular}

recalcitrance to enzymatic hydrolysis. The chemical compositions of biomass, which form a protective barrier to block the access of enzyme to substrate, are major causes of the recalcitrance of biomass. Among the chemical compositions of biomass, lignin is the most important component of cell wall recalcitrance to saccharification, especially in the process of enzymatic hydrolysis. Chen and Dixon [35] suggested that the recalcitrance of transgenic alfalfa to acid pretreatment and enzymatic hydrolysis was found to be proportional to the lignin content. Edmunds et al. [36] found that glucose release of transgenic Pinus taeda could increase 1.9- to 3.2-fold due to the reduction of lignin compared to the control. Davison et al. [37] found that the xylose yield of acid-hydrolyzed poplar genetic varieties with low lignin content and S/G ratio was $25 \%$ higher than those with high lignin content and S/G ratio. Mansfied et al.[38] manipulated lignin content to assess the effect of cell wall lignin on hydrolysis efficiency, and found that low-lignin plants showed up to a $15 \%$ increase in conversion rate, which was close to complete hydrolysis of cellulose polymers.

Although removing lignin can improve the efficiency of lignocellulose enzymatic hydrolysis, the complete removal of lignin is not necessary. This is because when the lignin removal rate reaches a certain level, the promotion effect of lignin removal on the enzymatic hydrolysis of the pretreated substrate gradually weakens. Zhang et al.[32] used DES (lactic acid and choline chloride) to treat the corncob at $90{ }^{\circ} \mathrm{C}$ for $24 \mathrm{~h}$ and found that once the delignification was over $70 \%$, the further removal of lignin would not promote the yield of reducing sugar. Moreover, the pretreatment process, especially those harsh methods that use strong acid or base, not only promote the delignification of biomass, but also facilitate the degradation of carbohydrates. In general, the pretreatment process that leads to a high lignin removal rate also results in a substantial sugar loss. Therefore, the promotion effect of high lignin removal rate on enzymatic saccharification may be neutralized by the sugar loss during the pretreatment process. It is necessary to find a balance between the removal of lignin and the loss of carbohydrate when designing a suitable pretreatment method for the enzymatic hydrolysis of lignocellulosic biomass [39]. In addition, excessive lignin removal results in high costs associated with processing, high chemical recovery cost, and poor environmental benefit. Therefore, future studies should be focused on optimizing pretreatment parameters under mild pretreatment conditions and recycling 
the chemical reagents to achieve high enzymatic hydrolysis efficiency with low capital and operation costs.

\section{Distribution of residual lignin in substrate}

In addition to lignin content, the deposition and redistribution of lignin are considered as crucial factors to determine the cell wall recalcitrance to enzymatic hydrolysis $[50,51]$. It has been reported that hydrothermal, ammonia fiber expansion (AFEX), steam explosion and dilute sulfuric acid pretreatment led to the migration and redistribution of lignin, which causes the structure changes of the lignocellulose matrix. Hydrothermal pretreatment induces the migration of lignin and results in the opening and dilation of pore volume and specific surface area, which facilitates enzymatic hydrolysis [52]. Wang et al. [53] observed that hydrothermal pretreatment effectively improved 3.5-fold fermentable sugars conversion compared with untreated biomass by removing hemicellulose and migrating lignin at $190{ }^{\circ} \mathrm{C}$ for $15 \mathrm{~min}$. AFEX pretreatment can disrupt the linkages in lignin-carbohydrate complex (LCC), partially deconstruct the hemicellulose and lignin and migrate lignin to the cell wall surface, resulting in the formation of porous structures. The porous structure further improved enzymatic hydrolysis efficiency [54]. Abdul et al. [55] observed that AFEX pretreatment could promote the enzymatic hydrolysis of oil palm empty fruit bunch. The removal and redistribution of lignin caused by AFEX pretreatment increased the accessibility of enzyme to cellulose. The liquid ammonia pretreatment also has been reported to result in the lignin relocation, which improves the enzyme access to cellulose [56]. Furthermore, Zhu et al. [57] found that ethylenediamine pretreatment exposed a more accessible surface of the substrate by the coalescence and relocalization of the lignin, thus enhancing the productive adsorption of cellulase to cellulose. In addition to the above pretreatment methods, steam explosion pretreatment also resulted in the improvement of enzymatic hydrolysis rate due to increased pore volume and specific surface area of the substrate caused by the redistribution and removal of lignin [58].

The condensation of lignin and the formation of pseudo-lignin have been reported to inhibit enzymatic hydrolysis. For example, the formation of spherical lignin droplets in the hydrothermal pretreatment shows the inhibitory effect on enzymatic hydrolysis [59]. Zhao et al. [60] reported that AFEX pretreatment at $2.0 \mathrm{~g} / \mathrm{g}\left(\mathrm{H}_{2} \mathrm{O}_{2} /\right.$ substrate) loading even increased the lignin content of moso bamboo compared to the raw material. This was due to the recondensation of lignin droplets to form new macromolecular lignin and the degradation of hemicellulose to form the pseudo-lignin. Similar observation also indicates that for the liquid hot water pretreatment, the hydrolysis rate of wheat straw gradually decreases over time due to the accumulation of lignin droplets on the surface of the hydrolyzed substrate [61]. Shinde et al. [62] reported that the formation of lignin-like polymer termed pseudo-lignin occurred in dilute acid pretreatment. Similar to residual lignin, pseudo-lignin plays a negative role in enzymatic hydrolysis because of its unproductive adsorption to the enzymes. For example, He et al. [63] observed that pseudo-lignin was formed by dehydration and aromatization of carbohydrates during dilute acid pretreatment, which absorbed the enzyme and reduced the efficiency of enzymatic hydrolysis. $\mathrm{Hu}$ et al. [64] also found that compared to a 50/50 mixture of pseudo-lignin and dilute acid pretreated lignin, pseudolignin had a greater inhibition impact on enzymatic hydrolysis, which was attributed to its high hydrophobicity induced by the methoxy and polyaromatic structures presented in pseudo-lignin. The redistribution of lignin can disrupt the compact structure of lignocellulose and result in the exposure of cellulose on enzyme, but lignin itself still remains harmful to enzymatic hydrolysis.

\section{Structural of residual lignin in substrate}

The S/G ratio and relative abundance of the three monomers of lignin have been found to have an impact on the enzymatic hydrolysis rate. Studer et al. [65] found that the high S/G ratio would be beneficial to the release of glucose and xylose of pretreated samples. The enzymatic hydrolysis rate of corn stover was much higher than that of switchgrass under the milder conditions of pretreatment and similar enzyme dosage [66]. Further studies found that the S/G ratio of lignin in corn stover was 1.4 and 0.8 in switchgrass [67-69], which was consistent with the finding that the high $\mathrm{S} / \mathrm{G}$ was related to less pretreatment severity and inhibition effect on enzymatic hydrolysis [70]. However, inconsistent results have also been reported. Xu et al. [71] found that the lignin with the high S/G ratio enhanced the non-productive adsorption of cellulase and was not conducive to the enzymatic saccharification of cellulose. Tan et al. [72] observed that a high S/G ratio of bisulfite pretreated oil palm empty fruit bunch lignin was negatively correlated with the enzymatic hydrolysis efficiency. Pape et al. [70] indicated that the S/G ratio of Eucalyptus wood had little effect on the saccharification efficiency of ionic liquid pretreated biomass.

For untreated biomass, Pape et al. [70] showed that a high $\mathrm{S} / \mathrm{G}$ ratio produced a lower enzymatic hydrolysis efficiency. Studer et al. [65] indicated that the enzymatic hydrolysis efficiency of untreated biomass was not correlated with the S/G ratio of lignin. Therefore, the consistency of the conclusion on the effect of the $S / G$ ratio on enzymatic hydrolysis of lignocellulose remains to be determined. 
The relative abundance of $\mathrm{G}, \mathrm{S}$, and $\mathrm{H}$ has been suggested to affect the enzymatic hydrolysis efficiency. Kim et al. [73] found that oxalic acid pretreated biomass was more pronounced to inhibit the enzymatic hydrolysis compared to sulfuric acid pretreated biomass, the reason for this is that the former contained a large amount of $\mathrm{G}$ unit lignin which had a high affinity for enzymes. Ko et al. [74] also found that softwood lignin-containing a higher $G$ unit had a stronger inhibition effect on enzymatic hydrolysis than hardwood lignin. Furthermore, the lignin extracted from woods has a more significant inhibition effect on enzymatic hydrolysis than the one extracted from herbaceous in which the lignin has a loose structure and a high $\mathrm{H}$ unit content [75]. Genetic engineering to change the three monomers' relative abundance is an alternative method to reduce cell wall structural recalcitrance and improve enzymatic hydrolysis efficiency and is especially effective in increasing the $\mathrm{S}$ monomer content to achieve a high hydrolysis yield $[76,77]$. This might result from the higher affinity of the $\mathrm{G}$ unit for enzymes than the $\mathrm{S}$ unit [74, 78]. Fu et al. [79] generated the switchgrass mutants with a reduced S/G ratio and the ethanol yield was increased by $38 \%$ compared to the native plants. Bonawitz et al. [80] created a new mutant of Arabidopsis whose lignin is almost entirely composed of $\mathrm{H}$ units, and saccharification efficiency was significantly increased.

The presence of hydroxycinnamates in lignin was found to affect the biomass recalcitrance. Ferulates (FA) and $p$-coumarates $(p \mathrm{CA})$ are two important hydroxycinnamates in grasses [81]. It was reported that the presence of FA makes the lignin close to the polysaccharide, thus increasing the recalcitrance of the substrate [82]. Reinoso et al. [83] suggested that the pretreated substrate was resistant to enzymatic hydrolysis due to the presence of ester-linked $p C A$. The cleavage and/or modification of FA and $p$ CA through some alkaline pretreatments could improve biomass digestibility. Yoo et al. [84] reported that ammonia pretreatment could crack FA cross-linkages and promote lignin depolymerization, thus improving the digestibility of biomass. Martínez et al. [85] found that $\mathrm{NaOH}$ pretreated simultaneously removed the xylan and $p C A$ in sugarcane bagasse, thus improving the cellulose accessibility thereof saccharification efficiency.

The linkages type of lignin in pretreatment has a significant impact on enzymatic hydrolysis of lignocellulose. The pretreatment results in the cleavage of original linkages and the formation of new linkages in lignin, thus changing the lignin properties. The cleavage of $\beta-O-4$ linkages can facilitate the disruption of cell wall matrix. For example, considerable $\beta-O-4$ linkages were broken in the autohydrolysis pretreatment of poplar [86] and the dilute acid pretreatment of switchgrass [69]. Lai et al. [87] prepared extractable lignin (EL) and milled wood lignin (MWL) isolated from ethanol organosolv pretreated wood sawdust. It was found that EL showed a lower inhibitory effect on enzymatic hydrolysis than MWL, due to its lower abundance of $\beta-5$ linkages. Jeong et al. [88] obtained LCC from raw materials and Fenton oxidationhydrothermal pretreatment of larch and yellow poplar and investigated their structural characteristics. They found that the contents of $\beta-\beta$ and $\beta-5$ in pretreated larch LCC were higher than those in pretreated yellow poplar LCC. Correspondingly, enzymatic hydrolysis efficiencies of pretreated yellow poplar and larch were $93.53 \%$ and $26.23 \%$, respectively. These findings indicated that the presence of $\beta-\beta$ and $\beta-5$ linkages in pretreated biomass was not conductive to enzymatic hydrolysis. However, due to the generation of more free phenolic hydroxyl, the cleavage of the $\beta-O-4$ linkages of lignin during the pretreatment may be detrimental to enzymatic hydrolysis. Yoo et al. [89] found that the content of $\beta-O-4$ linkages of residual lignin reduced significantly during the organosolv pretreatment of poplar. The consumption of $\beta-O-4$ linkages resulted in an increase in the phenolic hydroxyl content of lignin in pretreated poplar, thus increasing the adsorption capacity of cellulase onto the lignin fraction. In addition, the condensation of lignin through the formation of new carbon-carbon bonds generally occurred in the pretreatment step, leading to an increase in the hydrophobic interaction between the enzyme and lignin [90]. Song et al. [91] found that DES pretreatment of willow and corn stover caused their lignin fragments to undergo condensation reactions. The recondensation of lignin increased the hydrophobic interactions between lignin and cellulase, thus promoting the adsorption of cellulase onto lignin.

Lignin forms the LCC linkages with side chains of hemicellulose by covalent bonds, resulting in the lignocellulose recalcitrance [92]. Min et al. [93] found that the presence of LCC reduced enzyme accessibility to the substrate and inhibited enzymatic hydrolysis efficiency. Meanwhile, they also found that the LCC content was proportional to the $\mathrm{S}$ to vanillin $(\mathrm{V})$ ratio for a similar levels of lignin contents, and the higher the S/V ratio, the more obvious the inhibitory effect on enzymatic hydrolysis. Singh et al. [94] suggested that ammonia fiber explosion pretreatment improved enzymatic hydrolysis efficiency by breaking the LCC linkage between lignin and carbohydrate. Li et al. [95] indicated that the cleavage of LCC bonds by hydrothermal pretreatment is beneficial to improve the digestibility of cellulose, because LCC can contribute to the biomass recalcitrance.

Moreover, functional groups (methoxyl, phenolic hydroxyl, aliphatic hydroxyl, and carboxyl) of lignin affect the efficiency of enzymatic hydrolysis by altering the 
interactions between lignin and enzymes. Huang et al. [90] found that the phenolic hydroxyl group was associated positively with the unproductive adsorption of the cellulase on lignin, but negatively with the aliphatic hydroxyl group. Yu et al. [96] also investigated the effect of the hydroxyl groups on enzymatic hydrolysis using MWL and found that the cellulase adsorption on MWL was increased with the decrease of total hydroxyl. The decrease in aliphatic hydroxyl is the main reason for the change of total hydroxyl. A similar study also observed that lignin with high phenolic hydroxyl group content shows strong non-productive adsorption of cellulase [97]. The reason for these phenomena is that the cellulaselignin interaction was changed due to the formation of hydrogen bonds. Yang and Pan [98] found that the inhibition effect of lignin was reduced by hydroxypropylation reaction to block the free phenolic hydroxyl group. Carboxyl groups affect the adsorption capacity between lignin and enzyme by increasing the hydrophilicity and the negative charge of lignin. Ying et al. [99] found that alkali pretreatment combined with carboxylation posttreatment could increase the enzymatic efficiency by 1.5-3.4 times, which was attributed to the increase in the carboxylic group content of lignin after post-pretreatment. Guo et al. [100] found that MWL from corn stover had a stronger affinity with cellulase, due to its lower carboxyl content and higher phenolic hydroxyl content compared to lignin from kenaf and aspen. In addition, with regard to the effect of methoxyl on enzymatic hydrolysis, no correlation was found between methoxyl and enzymatic hydrolysis efficiency [101]. Qin et al. [102] investigated the relationship between methoxyl and enzymatic hydrolysis efficiency using lignin model compounds, and found that additional methoxyl had a positive or negative effect on enzymatic hydrolysis, which was related to the type of lignin model compound. The inconsistent correlation between functional groups and enzymatic hydrolysis may be related to biomass sources and pretreatment methods. In the future, a clearer impact of functional groups on enzymatic hydrolysis needs to be found.

The characteristics of lignin, including the content, distribution and structure, have an important influence on the enzymatic hydrolysis of lignocellulose. The pretreatment partially eliminates the negative effect of lignin on enzymatic hydrolysis by reducing the content of lignin [30]. The structure changes of lignocellulose caused by the redistribution of lignin can reduce the recalcitrance of lignocellulose and increase the accessibility of the enzyme to cellulose [52]. In addition, residual lignin with high S/G ratio and high carboxyl and aliphatic hydroxyl content is conducive to the enzymatic hydrolysis process. However, high contents of phenolic hydroxyl, hydroxycinnamates, $\beta-\beta, \beta-5$, and LCC linkages are detrimental to the enzymatic hydrolysis process $[65,81,88$, 100].

\section{Effect of introduced lignin on enzymatic hydrolysis Water-insoluble lignin (WIL) derived from different sources of biomass feedstock}

Various origins of lignin have been used to clarify the inhibitory effect on enzymatic hydrolysis, which is generally extracted from raw material or pretreated biomass using chemical solvent and recovered by precipitation. Lignin recovered under neutral or acidic conditions are mostly insoluble in water. The sources and extraction methods of lignin have an important impact on lignin chemistry and enzymatic hydrolysis efficiency. Most studies show that lignin can inhibit cellulose hydrolysis, and the inhibitory effect was related to the source of lignin, as reported by Zhang et al. [103] and Pan et al. [101]. Different from the conclusion that most lignins inhibit enzymatic hydrolysis, some lignin have little influence on the hydrolysis of pretreated biomass. Interestingly, several recent reports also suggested that some technical lignin have a boosting effect on enzymatic hydrolysis. For example, it was determined that the addition of ethanol organic solvent lignin significantly improved enzymatic hydrolysis efficiency [104, 105]. This may be because the polarities of ethanol and water are similar, and the ethanol organosolv lignin has a low $\mathrm{Mw}$ and allows itself partly water-soluble. Therefore, the enhanced hydrolysis conversion is caused by this part of the WSL. Moreover, an increase in hydrolysis yield can be achieved by increasing carboxyl content in isolated lignin preparations [106]. Jia et al. [107] investigated the effect of two extraneous lignin additives on the enzymatic hydrolysis of cellulose. The two lignin samples were taken from the $\gamma$-valerolactone/water pretreatment of corn stover. After, respectively, adding $2 \mathrm{~g} / \mathrm{L}$ of two lignins, the glucan conversion of cellulose was increased from $28.0 \%$ to $37.4 \%$ and $31.3 \%$. Hassanpour et al. [108] prepared the acid-glycerol (AG) pretreated sugarcane bagasse and dilute acid pretreated sugarcane bagasse and recovered the lignin from enzymatic hydrolysis residual of AG pretreated sugarcane bagasse. After adding lignin produced from AG pretreated process to the two substrates, lignin did not inhibit the enzymatic hydrolysis efficiency of AG pretreated sugarcane bagasse, but increased the enzymatic hydrolysis efficiency of dilute acid pretreated sugarcane bagasse from 33 to $38 \%$. In addition, Lan et al. [109] suggested that the addition of sugarcane bagasse lignin that recovered from the $p$-toluenesulfonic acid pretreatment hydrolysate reduced the adsorption of cellulase to sugarcane bagasse residue. While interestingly, due to the simultaneous decrease of the non-productive 
adsorption of cellulase onto lignin, the total enzymatic hydrolysis efficiency did not showed a detectable change. Wang et al. [110] found that the alkali lignin from liquid hydrothermal pretreated biomass had a little negative effect on the efficiency of enzymatic hydrolysis. Zhang et al. [103] also showed that ethanol lignin did not exhibit negative impact on cellulose hydrolysis, and even increased 5\% glucose yield when increasing the lignin content to $40 \%$. The effect of different WIL on enzymatic hydrolysis efficiency is summarized in Table 2.

The $\mathrm{Mw}$ of introduced lignin significantly influence the efficiency of enzymatic hydrolysis [111]. Li et al. [66] found that the deposition of high Mw lignin onto fiber surface is easy, and the deposited lignin further increased the steric hindrance. On the contrary, lower Mw lignin reduced the non-productive adsorption of enzyme onto lignin. During the autohydrolysis pretreatment of spruce, the addition of 2-naphthol and dimethylphloroglucinol significantly reduced the $\mathrm{Mw}$ of lignin and increased the enzymatic hydrolysis efficiency of the substrate by $39 \%$ and $42 \%$, respectively [112]. In addition, Lai et al. [105, 113] also observed that the addition of the organosolv lignin with low $\mathrm{Mw}$, which obtained from the organosolv pretreatment of biomass, facilitated the enzymatic conversion of pretreated lignocellulose. In general, low $\mathrm{Mw}$ lignin has a less inhibitory effect on enzymatic hydrolysis than high Mw lignin, and may even have a promoting effect. However, a few case showed that higher Mw lignin may be also beneficial for the enzymatic hydrolysis of pretreated biomass. For instance, Li et al. [17] found that maximum enhancement of the enzymatic hydrolysis of DA-pretreated rice straw and alkali-pretreated rice straw of $29 \%$ and $20 \%$ occurred for adding alkali lignin with higher Mw. In short, the influence of lignin on the enzymatic hydrolysis of lignocellulose is complicated. Further study on this topic is necessary and urgent.

To gain insight into the relationship between nonproductive adsorption and enzymatic hydrolysis, Langmuir model of adsorption isotherms has been adopted to measure the parameters for the adsorption of enzyme to different WILs, including the maximum adsorption capacity $\left(P_{\text {ad, }}\right)$, affinity $\left(K_{\mathrm{P}}\right)$ and bind strength $\left(P_{\mathrm{ad}}\right.$ $\left.{ }_{\mathrm{m}} \times K_{\mathrm{P}}\right)$. Nakagame et al. [114] found that the adsorption data of different source WILs are in good agreement with the Langmuir model of adsorption isotherm, with $K_{\mathrm{P}}$ and $P_{\text {ad, } \mathrm{m}}$ ranging from 0.48 to $4.19 \mathrm{~L} / \mathrm{g}$ protein and 32.03 to $81.99 \mathrm{mg} / \mathrm{g}$ lignin, respectively. The MWL from GL-SW and GL-HW absorbed the $68 \%$ and $40 \%$ cellulase and decreased the total sugar conversion by $4 \%$ and $13 \%$, respectively [96]. The hydrophilic modification of ethanol organosolv lignin resulted in the reduction of binding strength to cellulase from $3274.2 \mathrm{~mL} / \mathrm{g}$ lignin to 73.7 ,

Table 2 Inhibition effects of different WIL on enzymatic hydrolysis

\begin{tabular}{|c|c|c|c|c|c|}
\hline Lignin type & Enzyme & Substrate & Enzymatic hydrolysis & Hydrolysis yield & Refs. \\
\hline EOL-LP, EOL aspen and KPL & Cellic CTec 2 & DASG & $\begin{array}{l}\mathrm{pH}=4.8,50^{\circ} \mathrm{C}, 150 \mathrm{rpm} \text {, } \\
\text { and } 72 \mathrm{~h}\end{array}$ & $\begin{array}{l}\text { Decreased from } 27.0 \text { to } \\
20.0 \%\end{array}$ & {$[66]$} \\
\hline EOL-LP & Novozyme 22C & OPSG and OPLP & $\begin{array}{l}2 \%(\mathrm{w} / \mathrm{v}), \mathrm{pH}=4.8,50^{\circ} \mathrm{C} \text {, } \\
150 \mathrm{rpm} \text { and } 72 \mathrm{~h}\end{array}$ & $\begin{array}{l}\text { Decreased from } 49.3 \% \text { and } \\
41.2 \% \text { to } 42.0 \% \text { and } 38.1 \%\end{array}$ & {$[104]$} \\
\hline EOL-LP & $\begin{array}{l}\text { Celluclast and Novozyme } \\
188\end{array}$ & Avicel & $\begin{array}{l}2 \%(\mathrm{w} / \mathrm{v}), \mathrm{pH}=4.8,50^{\circ} \mathrm{C} \text {, } \\
150 \mathrm{rpm} \text { and } 48 \mathrm{~h}\end{array}$ & Decreased by 67.8-86.2\% & {$[98]$} \\
\hline HP & $\begin{array}{l}\text { Celluclast and Novozyme } \\
188\end{array}$ & Avicel & $\begin{array}{l}2 \%(\mathrm{w} / \mathrm{v}), \mathrm{pH}=4.8,50^{\circ} \mathrm{C} \text {, } \\
150 \mathrm{rpm} \text { and } 48 \mathrm{~h}\end{array}$ & Decreased by $23.0-76.0 \%$ & {$[98]$} \\
\hline $\mathrm{HEL}, \mathrm{KL}$ and $\mathrm{SEL}$ & $\begin{array}{l}\text { Celluclast and Novozyme } \\
188\end{array}$ & Avicel & $\begin{array}{l}2 \%(\mathrm{w} / \mathrm{v}), \mathrm{pH}=4.8,45^{\circ} \mathrm{C} \\
\text { and } 200 \mathrm{rpm}\end{array}$ & $\begin{array}{l}\text { Decreased by } 10.0 \%, 13.0 \% \\
\text { and } 23.0 \% \text {, respectively }\end{array}$ & {$[101]$} \\
\hline $\begin{array}{l}\text { PTL and CEL from steam } \\
\text { pretreated poplar }\end{array}$ & $\begin{array}{l}\text { Spezyme CP and Novo- } \\
\text { zyme } 188\end{array}$ & Avicel & $\begin{array}{l}5 \%(\mathrm{w} / \mathrm{v}), \mathrm{pH}=4.8,50^{\circ} \mathrm{C} \text {, } \\
150 \mathrm{rpm} \text { and } 48 \mathrm{~h}\end{array}$ & $\begin{array}{l}\text { Decreased by } 8.6 \% \text { and } \\
11.0 \% \text {, respectively }\end{array}$ & {$[75]$} \\
\hline PTL and CEL from OPLP & $\begin{array}{l}\text { Spezyme CP and Novo- } \\
\text { zyme } 188\end{array}$ & Avicel & $\begin{array}{l}5 \%(\mathrm{w} / \mathrm{v}), \mathrm{pH}=4.8,50^{\circ} \mathrm{C} \text {, } \\
150 \mathrm{rpm} \text { and } 48 \mathrm{~h}\end{array}$ & $\begin{array}{l}\text { Decreased by } 23.0 \% \text { and } \\
25.0 \% \text {, respectively }\end{array}$ & {$[75]$} \\
\hline EL from OPSG & Novozym 22C & OPSG & $\begin{array}{l}2 \%(\mathrm{w} / \mathrm{v}), \mathrm{pH}=4.8,50^{\circ} \mathrm{C} \text {, } \\
150 \mathrm{rpm} \text { and } 72 \mathrm{~h}\end{array}$ & $\begin{array}{l}\text { Improved from } 72.6 \text { to } \\
77.7 \%\end{array}$ & {$[105]$} \\
\hline EL from OPSG & Novozym 22C & OPSG and OPLP & $\begin{array}{l}2 \%(\mathrm{w} / \mathrm{v}), \mathrm{pH}=4.8,50^{\circ} \mathrm{C} \text {, } \\
150 \mathrm{rpm} \text { and } 72 \mathrm{~h}\end{array}$ & $\begin{array}{l}\text { Increased from } 49.3 \text { to } \\
68.6 \% \text { and from } 41.2 \text { to } \\
60.8 \%\end{array}$ & {$[104]$} \\
\hline $\begin{array}{l}\text { Liquid hot water treated } \\
\text { alkali lignin }\end{array}$ & Commercial cellulase & $\begin{array}{l}\text { filter paper and lignin } \\
\text { mixed }\end{array}$ & $\begin{array}{l}5 \%(\mathrm{w} / \mathrm{v}), \mathrm{pH}=4.8,50^{\circ} \mathrm{C} \text {, } \\
150 \mathrm{rpm} \text { and } 72 \mathrm{~h}\end{array}$ & Little inhibition effect & {$[110]$} \\
\hline EL from OPSG & Cellic CTec 2 & Cellulose & $\begin{array}{l}2 \%(\mathrm{w} / \mathrm{v}), \mathrm{pH}=4.8,50^{\circ} \mathrm{C} \text {, } \\
180 \mathrm{rpm} \text { and } 72 \mathrm{~h}\end{array}$ & No inhibition effect & {$[103]$} \\
\hline
\end{tabular}

EL extractable lignin, EOL-LP organosolv ethanol lignin from Lodgepole pine, EOL aspen ethanol organosolv lignins from aspen, KPL kraft pine lignin, $H P$ organosolv ethanol lignin from hybrid poplar, HEL hardwood ethanol organosolv lignin from Lignol, $K L$ kraft lignin from Aldrich, SEL softwood ethanol organosolv lignin from lignol, PTL protease treated lignin, CEL cellulolytic enzyme lignin, OPSG organosolv pretreated sweetgum, OPLP organosolv pretreated lodgepole pine, GLMP Green liquor pretreated masson pine, MP Masson pine, DASG Dilute acid pretreatment switchgrass 
44.4, 415.4 and $373.9 \mathrm{~mL} / \mathrm{g}$ lignin, thereby eliminating 76-96\% of lignin inhibition [98]. The ethanol organosolv lignin from sweetgum (EOL-SG) improved the enzymatic saccharification of organosolv pretreated loblolly pine by $38.8 \%$, while the organosolv ethanol lignin from lodgepole pine (EOL-LP) decreased the enzymatic saccharification of organosolv pretreated loblolly pine. Furthermore, the results from cellulase adsorption experiments indicated that the addition of EOL-SG decreased the cellulase adsorption to residual lignin from $61.1 \%$ to $33.2 \%$, while the addition of EOL-LP increased the cellulase adsorption to residual lignin from $61.1 \%$ to $77.7 \%$, which agreed with the effect of EOL-SG and EOL-LP on the enzymatic saccharification [115]. The dilute acid pretreated ERL (enzymatic residual lignin) was reported to hamper the cellulose hydrolysis, and the binding strength between dilute acid pretreated ERL and cellulase (261.5$410.9 \mathrm{~mL} / \mathrm{g})$ is higher than untreated ERL $(236.0 \mathrm{~mL} / \mathrm{g})$ [116]. These results clearly demonstrated that the enzyme adsorption properties were closely related to the enzymatic hydrolysis. In recent years, quartz crystal microbalance with dissipation (QCM-D) has been used to monitor the enzyme adsorption on isolated lignin in realtime. Rahikainen et al. [117] used QCM-D to study the enzyme binding with lignin, and observed that cellulase adsorption amounts were higher for steam explosion pretreated lignin compared to untreated lignin, and therefore, the former showed the stronger inhibition effect on hydrolysis reaction. Lai et al. [87] used QCM-D to calculate the cellulase adsorption parameter, and observed the EL has a lower maximum adsorption capacity (152.63$168.09 \mathrm{ng} / \mathrm{cm}^{2}$ ) compared to MWL (196.71-224.73 ng/ $\left.\mathrm{cm}^{2}\right)$, further the irreversible adsorption of EL $(75.40 \mathrm{ng} /$ $\left.\mathrm{cm}^{2}\right)$ is lower than MWL $\left(137.35 \mathrm{ng} / \mathrm{cm}^{2}\right)$, which is similar to increased enzymatic hydrolysis rate due to the presence of EL. The adsorption experiment with QCM-D found that fungal monocomponent enzymes (Cel6A and Cel7B) showed the high adsorption capacity and nonproductive adsorption towards the steam pretreated spruce lignin, with hydrolysis yield decreasing by $66 \%$ and $60 \%$, respectively [118].

Water-soluble lignin (WSL) derived from sulfite pretreatment liquor or modification/fractionation of original lignin

Contrary to the traditional view that lignin always plays a negative role in enzymatic hydrolysis, some recent studies have found that the addition of WSL increased the efficiency of enzymatic hydrolysis, as shown in Table 3. Currently, the WSL that promotes the enzymatic hydrolysis includes sulfonated lignin (SL), lignosulfonate (LS) and some low $\mathrm{Mw}$ lignin, such as kraft lignin and alkali lignin.

SL was obtained by modification of alkali lignin. It has been widely reported that the addition of LS increased the efficiency of enzymatic hydrolysis and reduced the non-productive adsorption of cellulase onto lignin [16]. Moreover, the enhanced hydrolysis efficiency is associated with buffer solution $\mathrm{pH}$. With increasing $\mathrm{pH}$ to 5.5 , LS increases the enzymatic digestibility of dilute acid pretreated and sulfite pretreated substrates by $10 \%$ and $20 \%$, respectively [119]. Similar behavior was also observed that for acid bisulfite pretreated polar, and the highest total sugar conversion achieved the $83.5 \%$ with $\mathrm{SL}$ addition, while the corresponding buffer solution $\mathrm{pH}$

Table 3 Inhibition effects of different WSL on enzymatic hydrolysis

\begin{tabular}{|c|c|c|c|c|c|}
\hline Lignin type & Enzyme & Substrate & Enzymatic hydrolysis & Hydrolysis yield & Refs. \\
\hline $\begin{array}{l}\text { Commercial sodium LS } \\
\text { from poplar }\end{array}$ & Cellic CTec 2 & Whatman filter paper & $\begin{array}{l}2 \%(\mathrm{w} / \mathrm{v}), \mathrm{pH}=4.8,50^{\circ} \mathrm{C} \text {, } \\
200 \mathrm{rpm} \text { and } 72 \mathrm{~h}\end{array}$ & $\begin{array}{l}\text { Improved by } 30.0 \% \text { to } \\
46.0 \% \text { with low Mw frac- } \\
\text { tion }\end{array}$ & [129] \\
\hline $\begin{array}{l}\text { LS from hydrolysate of } \\
\text { sulfite pretreated lodgepo- } \\
\text { ple pine }\end{array}$ & $\begin{array}{l}\text { Celluclast and Novozyme } \\
188\end{array}$ & Lodgepople pine & $\begin{array}{l}2 \%(\mathrm{w} / \mathrm{v}), \mathrm{pH}=5.5,50^{\circ} \mathrm{C} \text {, } \\
200 \mathrm{rpm} \text { and } 72 \mathrm{~h}\end{array}$ & $\begin{array}{l}\text { Improved from } 51.0 \text { to } \\
90.0 \%\end{array}$ & {$[119]$} \\
\hline Reax 85A & Cellic CTec 2 & $\begin{array}{l}\text { Acid bisulfite pretreated } \\
\text { poplar }\end{array}$ & $\begin{array}{l}2 \%(\mathrm{w} / \mathrm{v}), \mathrm{pH}=5.4,50^{\circ} \mathrm{C} \text {, } \\
180 \mathrm{rpm} \text { and } 48 \mathrm{~h}\end{array}$ & $\begin{array}{l}\text { Improved from } 76.4 \text { to } \\
83.5 \%\end{array}$ & {$[120]$} \\
\hline Commercial sodium LS & Cellic CTec 2 & $\begin{array}{l}\text { Kraft pulping produced } \\
\text { lodgepole pine }\end{array}$ & $\begin{array}{l}2 \%(\mathrm{w} / \mathrm{v}), \mathrm{pH}=4.8,50^{\circ} \mathrm{C} \text {, } \\
200 \mathrm{rpm} \text { and } 72 \mathrm{~h}\end{array}$ & $\begin{array}{l}\text { Improved from } 33.0 \text { to } \\
55.0 \%\end{array}$ & {$[121]$} \\
\hline $\begin{array}{l}\text { LS from sulfite pretreated } \\
\text { poplar }\end{array}$ & Cellulase mixture & Sulfite pretreated poplar & $\begin{array}{l}2 \%(\mathrm{w} / \mathrm{v}), \mathrm{pH}=4.8 \text { or } 5.2, \\
50{ }^{\circ} \mathrm{C}, 200 \mathrm{rpm} \text { and } 96 \mathrm{~h}\end{array}$ & $\begin{array}{l}\text { Improved by } 5 \% \text { to } 9 \% \text {, } \\
\text { respectively, at } \mathrm{pH} 4.8 \text { and } \\
\mathrm{pH} 5.2\end{array}$ & {$[130]$} \\
\hline $\begin{array}{l}\text { LS from poplar sulfite } \\
\text { pulping }\end{array}$ & Cellic CTec 2 & A mixture of the cellulose & $\begin{array}{l}2 \%(\mathrm{w} / \mathrm{v}), \mathrm{pH}=4.8,50^{\circ} \mathrm{C} \text {, } \\
200 \mathrm{rpm} \text { and } 72 \mathrm{~h}\end{array}$ & $\begin{array}{l}\text { Improved from } 52.0 \text { to } \\
67.0 \%\end{array}$ & [123] \\
\hline $\begin{array}{l}\text { Water-soluble alkaline } \\
\text { lignin }\end{array}$ & Cellic CTec 2 & $\begin{array}{l}\text { Sodium } \\
\text { hydroxide pretreated } \\
\text { wheat straw }\end{array}$ & $\begin{array}{l}2 \%(\mathrm{w} / \mathrm{v}), \mathrm{pH}=4.8,50^{\circ} \mathrm{C} \text {, } \\
180 \mathrm{rpm} \text { and } 72 \mathrm{~h}\end{array}$ & $\begin{array}{l}\text { Improved from } 66.8 \text { to } \\
76.9 \%\end{array}$ & [122] \\
\hline $\begin{array}{l}\text { Reax } 85 \mathrm{~A} \text { (sulfomethylated } \\
\text { softwood kraft lignin) }\end{array}$ & Cellic CTec 2 & GLMP & $\begin{array}{l}5 \%(\mathrm{w} / \mathrm{v}), \mathrm{pH}=4.8,50^{\circ} \mathrm{C} \text {, } \\
180 \mathrm{rpm} \text { and } 96 \mathrm{~h}\end{array}$ & $\begin{array}{l}\text { Improved from } 42.0 \text { to } \\
75.0 \%\end{array}$ & {$[16]$} \\
\hline
\end{tabular}


was 5.4 instead of 4.8 [120]. LS can be prepared from the sulfite pulping black liquor. Zhou et al. [121] found that LS improved the hydrolysis yield of three different types of lignocellulose substrates, and noticed that low Mw LS fractions were more effective to enhance the enzymatic hydrolysis efficiency than high Mw LS fractions. The addition of LS to pretreated lignocellulose containing hydrophobic lignin led to a higher enhancement of enzymatic saccharification than those of adding LS to pretreated lignocellulose containing relatively hydrophilic lignin. Similar studies also found that LS was beneficial to enzymatic hydrolysis of acidic bisulfite pretreated and green liquor pretreated poplar, but had no effect on sulfite-formaldehyde pretreated poplar [16]. These phenomena suggest that the effect of LS on enzymatic hydrolysis is related to the residual lignin, and that WSL promotes the cellulose hydrolysis most likely related to the "competitive" adsorption of WSL and residual lignin to cellulase.

In addition, soluble alkali lignin and kraft lignin also have a positive effect on enzymatic hydrolysis. Jiang et al. [122] found that soluble alkali lignin from pulping spent liquor promoted the enzymatic hydrolysis of wheat straw, so they proposed a method to improve the hydrolysis efficiency of lignocellulose by adding soluble alkali lignin. Kraft lignin is prepared by acid deposition and contains a fraction of soluble kraft lignin. The soluble kraft lignin binds to cellulase and counteracts the inhibitory effect of insoluble kraft lignin on enzymatic hydrolysis, which also provides evidence that insoluble kraft lignin has no significant inhibitory effect on enzymatic hydrolysis [123].

Based on the inspiration that WSL can increase the efficiency of enzymatic hydrolysis, attention has been paid to the hydrophilic modification of lignin reduced the inhibitory effect of lignin on enzymatic hydrolysis $[124,125]$. Sulfonation modification, oxidation modification and carboxylation modification of alkali lignin [99] can reduce the lignin contact angle by $61.0-70.0 \%$, and correspondingly lower the unproductive adsorption of cellulase. Similarly, sulfonation and carboxylation modifications of lignin [98] also increased the hydrophilicity of lignin and greatly improved enzymatic hydrolysis efficiency of Avicel by $8.0-15.3 \%$ compared with the unmodified lignin. These conclusions also support the phenomenon that the sulfite pretreated biomass feedstock has a high enzymatic saccharification efficiency [126-128]. Another study also found that alkali lignin inhibited the efficiency of enzymatic hydrolysis, but the alkali lignin modified by PEG1000 led to relatively high efficiency of enzymatic hydrolysis [123]. In general, the hydrophilic modification of lignin could reduce the non-productive adsorption of cellulase onto lignin and improve the efficiency of enzymatic hydrolysis. This phenomenon indicates that the non-productive adsorption mediated by hydrophobic interactions is the main reason for low enzymatic saccharification efficiency. The finding that WSL improves enzymatic hydrolysis efficiency allows to add high value to lignin and enables the fullcomponent utilization of lignocellulose.

The effect of introduced lignin on enzymatic hydrolysis has been widely studied in recent years. Most waterinsoluble lignin has an inhibitory effect on enzymatic hydrolysis, and the inhibitory effect is different, depending on the pretreatment methods and the source of lignin [101]. Nevertheless, some water-insoluble lignins with lower $\mathrm{Mw}$ also exhibit a promoting effect on enzymatic hydrolysis [111]. In recent years, water-soluble lignin derived from sulfite pretreatment liquor or modification/ fractionation of isolated lignin has been found to promote the efficiency of enzymatic hydrolysis [16]. Hydrophilic modification of introduced lignin is an effective strategy to improve the efficiency of enzymatic hydrolysis [123].

\section{Interaction between lignin and cellulase}

The understanding of enzyme-lignin interactions is essential for reducing the inhibitory effect of lignin and enhancing the hydrolysis yield. However, due to the heterogeneity of the lignin from different sources, the mechanism of inhibition is still unclear. Currently, it is well-known that lignin hinders the efficiency of enzymatic hydrolysis in three main ways: (1) steric hindrance; (2) non-productive adsorption; (3) inhibitory effects of soluble phenols compounds (Fig. 2).

\section{Steric hindrance}

The steric hindrance of lignin is an important factor to block the enzymatic hydrolysis except for unproductive adsorption. Vermaas et al. [132] simulated the interaction between cellulase and model biomass containing cellulose and lignin and found that lignin bound to the hydrophobic surface of cellulose, causing steric hindrance, hindering productive adsorption between enzyme and cellulose, and delaying enzymatic hydrolysis. Djajadi et al. [133] showed that hydrothermally pretreated grass biomass lignin acts as a physical barrier to hinder enzymatic degradation of cellulose, rather than induces the inhibition by non-productive adsorption of enzymes. In addition, the pretreatment of the biomass raw material also contributes to the formation of physical barrier. For example, lignin droplets and the pseudo-lignin formed during the pretreatment can block the productive binding of cellulase and cellulose [134]. Moreover, the deposition and redistribution of lignin on the cellulose surface also block the access of enzymes to cellulose $[135,136]$. 


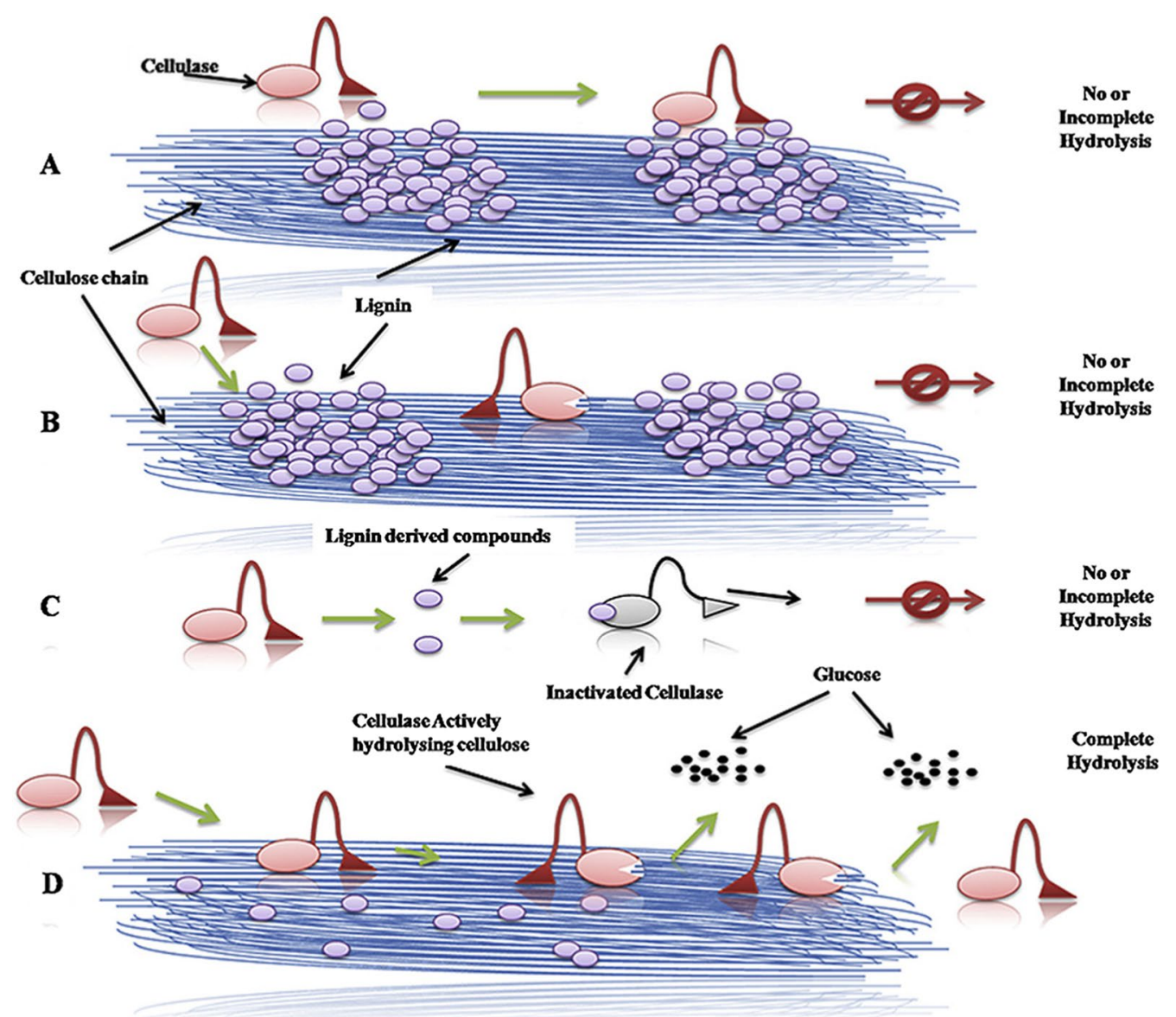

Fig. 2 Non-productive adsorption of cellulase onto lignin (A), physical blockage of cellulase progress on lignocellulose chain (B), enzyme inhibition due to soluble lignin-derived compounds $(\mathbf{C})$, and normal functioning of cellulase on cellulose chain to release glucose in presence of no or very low amount of lignin (D) [131]

\section{Unproductive adsorption of enzyme on lignin}

Unproductive adsorption is considered to be a key mechanism for lignin to inhibit enzymatic hydrolysis (Fig. 3). Martín-Sampedro et al. [137] reported that both Cel7A and Cel7B have strong binding to cellulose and lignin, but Cel7B has a strong affinity with lignin, causing a broader effect on cellulose hydrolysis reaction. Yarbrough et al. [6] found that there is almost no $\beta$-glucosidase and endoglucanase enzyme proteins in the presence of lignin using gel electrophoresis analysis, which shows that the lignin inhibits the enzyme activity through adsorption. Qin et al. [138] indicated that the adhesion forces between kraft lignin and cellulase were higher than forces between hydroxypropyl cellulose and cellulase, which indicated that hydrophobic interaction seems to be the main attraction force for cellulase to bind lignin. The non-productive adsorption of enzyme onto lignin is categorized into three types of driving force: hydrophobic interactions, electrostatic interactions, and hydrogen bonding; whereas which one plays a dominant role depends on the complexity of the lignin structure from different sources, the type of the enzyme, and the experimental conditions. The three interactions are described below.

\section{Hydrophobic interactions}

Hydrophobic interaction is thought to be the main mechanism for the unproductive adsorption of enzymes and lignin [140]. After the cellulase is dispersed in water, the hydrophobic group of the cellulase stretches in the aqueous solution, which makes the hydrophobic cellulase and the solid surface adsorb together due to the hydrophobic interaction. Thus, enzymes having different hydrophobicity show different adsorption on lignocellulose substrates. Hydrophobic interaction is strongly related to the cellulose binding domain (CBM) of cellulase that is composed of specific amino acid sequences. For example, the hydrophobicity of CBM in Cel7B is higher than that of Cel7A, so that Cel7B more easily adsorbs on lignin 


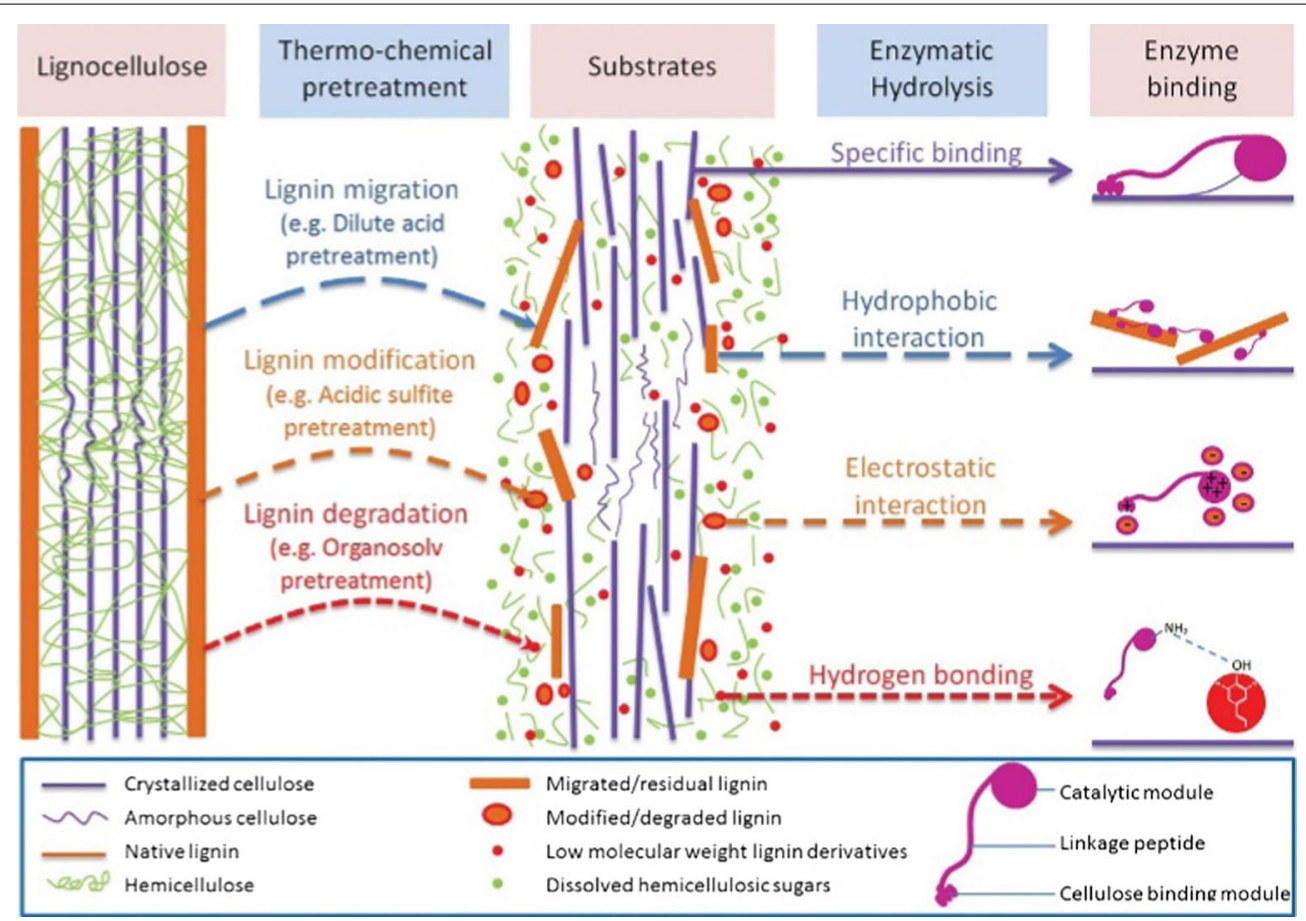

Fig. 3 Schematic illustration of cellulase-lignin interactions dependent on lignin alteration during biomass pre-treatment [139]

[141]. In addition, it has been found that the inhibition effect was related to the cellulase component. Lu et al. [142] observed that lignin has the greatest reduction in Cel7A enzyme activity, followed by xylanase, then by EGs (Cel5B, Cel5C, and Cel7B) and $\beta$-glucosidase.

In addition to the hydrophobicity of cellulase, the hydrophobicity of lignocellulose as a solid substrate will also affect the adsorption of cellulase on the substrate, and the presence of lignin will increase the hydrophobicity of the substrate. The same conclusion was further verified by other researchers, when using films prepared by a spin coater to measure the hydrophobicity of different lignins (softwood sulfate lignin, softwood and hardwood MWL) and cellulose [143-145]. These studies proved that the hydrophobicity of lignin and enzymes played an important role in the non-productive adsorption of cellulase onto lignin, and were related to the reduction of lignocellulose hydrolysis efficiency.

\section{Electrostatic interactions}

Electrostatic interaction is also responsible for the nonproductive adsorption of enzymes onto lignin. In general, the enzyme surface is ionic-charged due to the presence of carboxyl, amino and phosphate groups, etc. The net charge of enzyme molecules is related to its isoelectric point $(\mathrm{pI})$, component and solution $\mathrm{pH}$. For example, when the solution $\mathrm{pH}$ is above the $\mathrm{pI}$, the cellulase is negatively charged, otherwise positively charged.
Most cellulases used for enzymatic hydrolysis have pI values $\leq 4.8$, showing a positively charge at the enzymatic hydrolysis reaction $(\mathrm{pH}=4.8-5.0)$. In addition, the charge carried by cellulase is also related to their compositions. During solution pH of 4.8 to 5.0, Cel6A, Cel12A and $\beta$-glucosidase from Trichoderma reesei are positively charged, while Cel7A, the Cel7A core, Cel7B and Cel5A are negatively charged [114]. On the other hand, lignin isolated after pretreatment usually contains carboxyl, phenol hydroxyl and alcohol hydroxyl groups [146], and sulfonation-modified lignin also has sulfonic acid groups. Lignin is usually negatively charged under acidic enzymatic hydrolysis conditions $(\mathrm{pH}=4.8-5.0)$, so electrostatic attraction usually occurs between cellulase and lignin. Moreover, some researchers showed that electrostatic interaction is related to the changes in $\mathrm{pH}$. Baig et al. [147] observed that the adsorption of lignin and cellulase was significantly reduced in an elevated $\mathrm{pH}$ of 4.8 to 5.5 . The decrease in the adsorption of cellulase to lignin is due to the increase in the negative charge of the cellulase at raised $\mathrm{pH}$, thereby enhancing the electrostatic interaction. Lou et al. [148] showed that at an elevated $\mathrm{pH}$ from 4.5 to 6.0 , the negativity of the zeta potential of lignin in softwood isolated by cellulolytic enzyme and protease was increased, thereby increasing the hydrophilicity of lignin and reducing its affinity towards cellulase. This study contradicts the recognized concept that the optimal $\mathrm{pH}$ value for enzymatic hydrolysis is 4.8-5.0. 
This finding has certain scientific and practical significance, since increasing the $\mathrm{pH}$ is easy to implement commercially at low capital costs.

\section{Hydrogen bonding interactions}

Hydrogen bonding interactions between cellulase and lignin have also been reported in several studies. The hydrogen bonds are thought to be formed between the hydroxyl groups in cellulose and lignin. The phenolic hydroxyl group in lignin is mainly involved in the adsorption of cellulase to lignin driven by hydrogen bonding. Due to the higher content of phenolic hydroxyl group in organosolv lignin, it is more effective than steam explosion lignin for cellulase adsorption. However, during the hydrolysis of filter paper, the addition of hydroxypropyl organosolv lignin enhances the hydrolysis yield compared to the addition of steam pretreated lignin [149]. Qin et al. [138] used atomic force microscopy (AFM) to measure the adhesion forces between lignin and enzyme and found that hydrogen bonding promoted the ligninenzyme interaction to some extent. Zhang et al. [150] found that the addition of the surfactant such as PEG could form the hydrogen bonding with the phenolic hydroxyls of lignin, which prevented the non-productive adsorption of cellulase onto lignin through hydrogen bonding. In addition, aliphatic hydroxyl groups in lignin have been reported to be involved in hydrogen bond formation as well. However, the negative impact of lignin on the enzymatic hydrolysis of pretreated substrates may be reduced by increasing its hydrophilicity due to the presence of carboxylic acid in lignin [106]. Unfortunately, few researches have reported the effect of hydrogen bonds on the non-productive adsorption of cellulase onto lignin. Hence, to provide theoretical guidance for enzymatic hydrolysis, further experiments about the hydrogen bonding interaction still needed be conducted.

\section{Inhibition effect of soluble lignin-derived phenolic compound}

The high pretreatment severity can result in the formation of soluble lignin-derived phenolic compounds [151]. When exposed to lignin-derived phenolic compounds, the enzyme will be immediately inactivated, causing a steady loss of enzymatic activity with the prolonged exposure to phenolic compounds [152, 153]. The inhibitory effect based on phenolic compounds is attributed to the co-precipitation with cellulase, depending on the microbial origin of cellulase, the types of enzyme and phenolic compounds [77, 154]. Kim et al. [155] carried out post-pretreatment washing on steam explosion pretreated mixed hardwood, and found that the addition of washate concentrates significantly reduced the glucose yield from 88 to only $20-30 \%$. The inhibitory effect mainly comes from phenolic compounds of lignin (concentrations between $0.5-1.0 \mathrm{~g} / \mathrm{L}$ ), which are identified as gallic acid, syringic acid and guaiacol/ coniferyl alcohol. The $\beta$-glucosidase from Trichoderma reesei is more susceptible to inhibition by phenolic compounds than the $\beta$-glucosidase from Aspergillus niger $[153,156]$. It has been proven that supplementing Trichoderma reesei cellulase with a high $\beta$-glucosidase enzyme formulation from Aspergillus niger can effectively enhance overall cellulase activity. At present, some strategies have been used to alleviate the inhibition effect of phenolic compounds. Peciulyte et al. [157] reported that in commercial enzyme preparations modified by the addition of lytic polysaccharide monooxygenases, phenolic compounds are actually beneficial, because these enzymes need reduce the equivalents to function. The study found that selecting the Miscanthus grass and wheat straw with less recalcitrance feedstocks can make hydrothermal pretreatment perform under mild conditions, which effectively reduces the release of phenolic compounds [158].

\section{Mechanisms of interactions on WSL and cellulase}

WSL, as a novel additive, is widely believed to decrease non-productive adsorption of cellulase onto lignin and promote enzymatic hydrolysis. Established data showed that the promoting effect of WSL on enzymatic hydrolysis could be related to the lignin-cellulase complex formed by the binding of WSL and cellulase, which is the key mechanism for WSL to promote enzymatic hydrolysis. Previous research indicated that LS contains the same ionizable groups as other anionic polyelectrolytes, which can bind to BSA with the formation of LSBSA complex [159]. Similarly, Wang et al. [130] reported that LS could bind with cellulase to form a hydrophilic cellulase-LS complex, making the cellulase a more negative charge than the original. Therefore, although LS is a lignin derivative, it reduces the interaction between enzyme and lignin by weakening hydrophobic and electrostatic interactions. Zheng et al. [160] reported that the addition of LS led to the formation of LS-DA-SCB (dilute acid pretreated sugarcane bagasse) lignin complexes and LS-cellulase complexes, which increases the electrostatic repulsion between cellulase and DA-SCB lignin and results in the increased binding site of cellulase to cellulose, thereby reducing the non-productive adsorption of cellulase onto DA-SCB lignin (Fig. 4A). LS, as a surfactant can reduce the non-productive adsorption of enzymes onto lignin. Leu and Zhu [161] showed that LS can function as a surfactant to reduce non-productive adsorption and increase enzyme activity. Zhou et al. [121] also speculated that LS, with a low affinity for cellulase due to its hydrophilic surface, acts as a surfactant to block the site of residual lignin on cellulase, thus reducing 
A

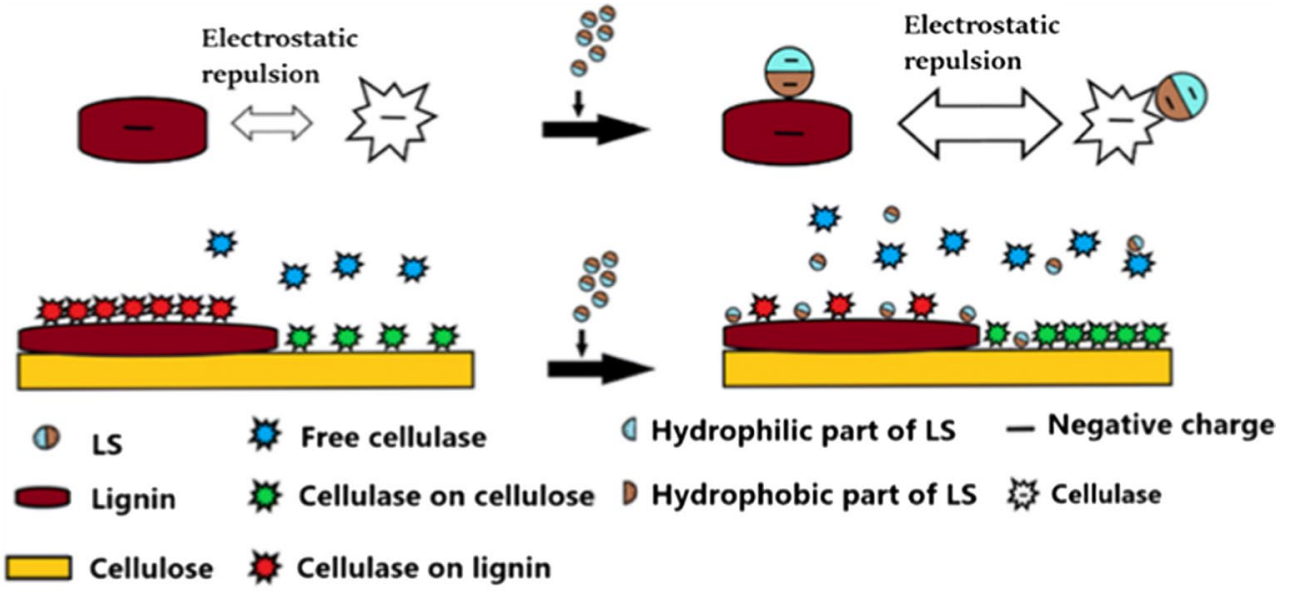

B

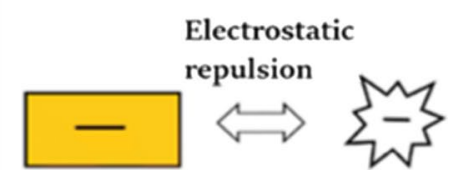

Electrostatic
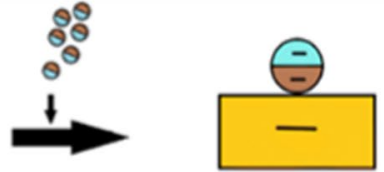

Electrostatic repulsion
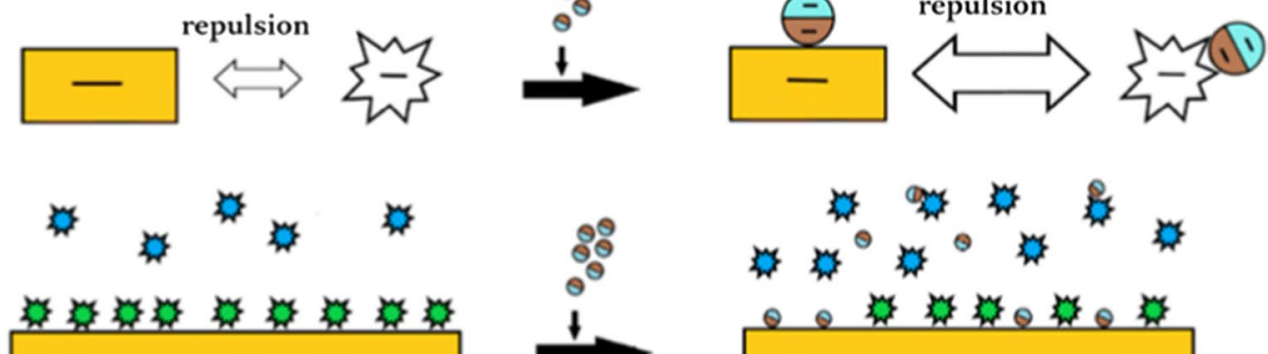

(1) LS

Cellulose
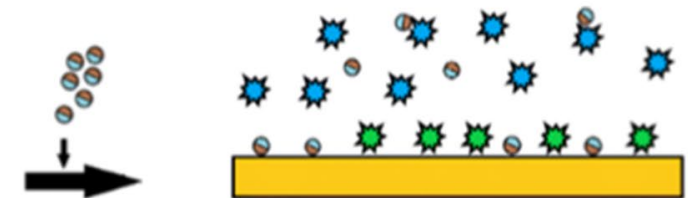

- Negative charge Cellulase
Hydrophilic part of LS Cellulase on cellulose

D Hydrophobic part of LS Free cellulase

Fig. 4 Schematic diagram of cellulase adsorption on lignocellulose (DA-SCB) before and after adding LS (A) and schematic diagram of cellulase adsorption on pure cellulose (Avicel) before and after adding LS (B) [160]

the non-productive binding of cellulase onto lignin and improving the enzymatic saccharification of lignocellulose. In addition to LS, lignin-PEG (the modified isolated lignin) has been developed to reduce the non-productive of cellulase onto lignin by dispersing cellulase aggregates [162].

LS has been extensively believed to hinder the pure cellulose enzymatic hydrolysis. Zheng et al. [160] showed that LS could bind to Avicel and form the Avicel-LS complexes, which occupied the binding site of cellulase and Avicel, thus lowering the productive adsorption of cellulase on Avicel (Fig. 4B). This finding was also confirmed in the studies of Wang et al. [119] and Liu et al. [163]. They suggested that the non-productive adsorption of cellulase onto LS is the main reason for the inhibition. Nevertheless, few researchers have also found that LS could promote the hydrolysis of pure cellulose. Lou et al. $[123,129]$ observed that adding three commercial sodium lignosulfonates with different Mw could improve the enzymatic hydrolysis efficiency of pure cellulose. The authors thought that the LS-cellulase complex could improve and stabilize the binding of cellulase and cellulose. Zhou et al. [121] found that low Mw SL promotes the efficiency of enzymatic hydrolysis of pure cellulose. The mechanisms of WSL promoting enzymatic hydrolysis of lignin-containing biomass are mainly categorized into two types: (1) The addition of WSL leads to competitive adsorption of WSL with residual lignin, forming the WSL-cellulase complexes; (2) The WSL acts as a surfactant to stabilize the cellulase and increase the accessibility of enzyme to cellulose $[130,161]$. However, most WSL has an inhibitory effect on pure cellulose substrates. This inhibition effect is attributed to the non-productive adsorption of cellulase onto WSL, thereby reducing the avaliable adsorption sites of cellulase on cellulose [163]. Overall, although it has been extensively reported that 
the formation of WSL-cellulase complexes can promote the enzymatic hydrolysis of lignin-containing substrates, it is not yet fully understood how complexes impacts the lignin-enzyme interaction, and thus the effect mechanism of WSL on lignocellulose still needs to be further explored.

\section{The newly advanced technology to elucidate lignin- enzyme interactions}

In the past few years, various advanced analysis techniques have been used to elucidate the interaction between lignin and cellulase, including quartz crystal microbalance with dissipation (QCM-D), surface plasmon resonance (SPR), atomic force microscopy (AFM), Fourier transform attenuated total reflection infrared spectroscopy (FTIR-ATR), nuclear magnetic resonance (NMR) spectroscopy, fluorescence spectroscopy (FLS), and molecular dynamics (MD) simulations. Among them, QCM-D, SPR, and AFM have made greater progress in clarifying the interaction between lignin and cellulase.

QCM-D was widely used to observe the adsorption/desorption and kinetics of cellulase on the cellulose/lignin thin film in real time. He et al. [164] applied QCM-D to study the effect of pseudo-lignin and residual lignin on enzymatic hydrolysis. The dynamics of enzymatic hydrolysis showed that when pseudo-lignin and residual lignin were mixed with cellulose, the maximum glucose release was reduced and the time to reach the maximum enzymatic hydrolysis efficiency was longer than that of pure cellulose. Jiang et al. [165] prepared a full-component lignocellulose ultrathin film using the $\mathrm{LiCl} / \mathrm{DMSO}$ solvent system. The in situ enzymatic hydrolysis of the film in QCM-D verified the non-productive adsorption of cellulase onto lignin.

SPR is another technology to explore lignin-enzyme interactions by simulating adsorption-desorption model. It is an optical technology that can be used to detect the thickness and structure changes of the ultrathin adsorption layer on the metal surface [166]. SPR could been used to study the kinetic parameters of the adsorption of cellulase onto lignin films during the enzymatic hydrolysis process [167]. Pereira et al. [168] used SPR to conduct the enzyme adsorption experiments in buffer solutions with different ionic strengths. The authors found that electrostatic interaction plays an important role in the adsorption of various types of lignin to cellulase. The mechanism of amphiphilic lignin derivatives promoting enzymatic saccharification was also studied using SPR [169].

Using AFM can directly measure specific interaction forces between lignin and cellulase and obtain surface images. Furthermore, AFM probes can be modified to have specific chemical characteristics, allowing AFM to measure the interaction between specific materials and molecules. Arslan et al. [170] used AFM to measure the nanoscale steric forces between a model surface with hydrophobic residues of cellulase and biomass substrates pretreated by different methods. The results indicated that organosolv pretreatment should be the first choice to reduce the non-productive adsorption of enzymes onto lignin. AFM has been also used to measure the nanoscale forces between the carbohydrate binding module (CBM) of Cel7A and three lignocellulosic substrates. The results indicated that the overall adhesion forces of substrates to CBM were proportional to the surface lignin coverage. The authors also suggested that changing the surface hydrophobicity and surface energy of lignin is a prerequisite to avoid the non-productive adsorption of cellulase onto kraft lignin [171].

\section{Conclusions and prospects}

Enzymatic hydrolysis of biomass is a key step for lignocellulose bioethanol production via sugar platform. However, lignin endows the biomass recalcitrance of lignocellulose and irreversibly adsorbs cellulase, thus reducing the hydrolysis efficiency. The lignin content, distribution and structural characteristics in substrate have been found to influence the non-productive adsorption of cellulase onto lignin. In addition, due to the complex structure of lignin, the inhibitory effect of introduced water-insoluble lignin on enzymatic hydrolysis varies with the sources of lignin. Interestingly, adding water soluble lignin to the hydrolysis system can reduce the non-productive adsorption of cellulase onto lignin and promote hydrolysis. The hydrophobic, hydrogen bonding and electrostatic interactions are the main causes of the non-productive adsorption of cellulase onto lignin. The formation of the WSL-cellulase complexes is crucial to improve the enzymatic hydrolysis efficiency of pretreated substrates. In recent years, the development of some advanced technologies (QCM-D, SPR, and AFM) provides new insights for elucidating the lignin-enzyme interactions.

However, the removal of lignin by pretreatment is costly and adversely affect the environment. It also leads to the condensation of lignin and the formation of pseudo-lignin, reversely increasing the non-productive adsorption of cellulase onto lignin. Therefore, the selection of suitable pretreatment methods along with appropriate surface modification of lignin is an effective pathway to regulate the interaction between cellulase and lignin. Genetic engineering to change the content of lignin and regulate its biosynthesis should be more considered. Although the lignin-enzyme interaction has been extensively studied, its influence on enzymatic 
hydrolysis is still unclear due to the complexity of the structure of lignin and enzymes. Understanding the interactions between lignin and cellulase, such as hydrophobic interaction, hydrogen bonding and electrostatic association, is the prerequisite for improving the efficiency of enzymatic hydrolysis. Much attention should be paid to establish the relationship between the lignin molecular structure and lignin-enzyme interaction from fundamental points of view to optimize the enzymatic hydrolysis. Moreover, the hydrophobic interaction is thought to be coupled with the other two interactions to drive the non-productive adsorption of cellulase onto lignin. Therefore, how to identify hydrophobic, electrostatic, and hydrogen bond interactions between lignin and cellulase, and understand the influence of single factors on enzymatic hydrolysis is one of the challenges in the future. In addition, it is worth emphasizing that the conversion of lignin into stimulant additives, for example, lignosulfonate from sulfite pretreatment, is a cost-effective method to improve the hydrolysis yield, but the mechanism still needs be further explored. To fully unlock the lignin-enzyme interactions at the molecular level as well as the promoting effect of lignosulfonate on enzymatic hydrolysis, more state-of-the-art analytical techniques should be adopted in elucidating the lignin-enzyme interactions in future studies, and the findings are beneficial to reducing the negative effect of lignin on enzymatic hydrolysis and provide a pathway to utilize the enzymes more efficiently and cost-effectively.

\section{Abbreviations \\ AFEX: Ammonia fiber expansion; BSA: Bovine serum protein; FA: Ferulates; pCA: $p$-Coumarates; PEG: Polyethylene glycol; SN: Syringaldehyde to vanillin ratio; MWL: Milled wood lignin; WIL: Water-insoluble lignin; QCM-D: Quartz crystal microbalance with dissipation; AFM: Atomic force microscopy; SPR: Surface plasmon resonance; WSL: Water-soluble lignin; SL: Sulfonated lignin; LS: Lignosulfonate; LCC: Lignin-carbohydrate complex; EL: Extractable lignin; Mw: Molecular weight; EOL-LP: Ethanol organosolv lignins from lodgepole pine; EOL aspen: Ethanol organosolv lignins from aspen; KPL: Kraft pine lignin; HP: Ethanol organosolv lignin from hybrid poplar; HEL: Hardwood ethanol organosolv lignin from lignol; KL: Kraft lignin from Aldrich; SEL: Softwood etha- nol organosolv lignin from lignol; PTL: Protease treated lignin; CEL: Cellulolytic enzyme lignin; OPSG: Organosolv pretreated sweetgum; OPLP: Organosolv pretreated lodgepole pine; GL: Green liquor; GLMP: Green liquor pretreated masson pine; MP: Masson pine; DASG: Dilute acid pretreatment switchgrass; CBM: Cellulose binding domain; pl: Isoelectric point; DA-SCB: Dilute acid pretreated sugarcane bagasse.}

\section{Acknowledgements}

We are grateful for the financial support from the National Natural Science Foundation of China (grant numbers 31730106, 22078162, 21704045) and A Project Funded by the National First-class Disciplines (PNFD)

\section{Authors' contributions}

YFY wrote the manuscript. HC, WJW and SFW provided some suggestions on manuscript writing. BJ, YCJ and HNX revised the manuscript. All authors read and approved the final manuscript.
Funding

The National Natural Science Foundation of China (Grant Numbers 31730106, 22078162, 21704045), Jiangsu Province Key Research and Development Plan (BE2021368), and 333 Project of Jiangsu Province (BRA2019070).

\section{Availability of data and materials}

Not applicable.

\section{Declarations}

Ethics approval and consent to participate

Not applicable.

\section{Consent for publication}

All authors read and approved the final manuscript for publication.

\section{Competing interests}

The authors declare no conflict of interest.

\section{Author details}

1 Jiangsu Co-Innovation Center of Efficient Processing and Utilization of Forest Resources, Nanjing Forestry University, Nanjing 210037, China. ${ }^{2}$ Department of Chemical Engineering, University of New Brunswick, Fredericton, NB E3B 11 $5 \mathrm{~A} 3$, Canada. ${ }^{3}$ Laboratory of Wood Chemistry, Nanjing Forestry University, 159 Longpan Rd, Nanjing 210037, China.

Received: 28 June 2021 Accepted: 10 October 2021

Published online: 20 October 2021

\section{References}

1. McKendry P. Energy production from biomass (Part 1): overview of biomass. Bioresour Technol. 2002;83(1):37-46.

2. Capolupo L, Faraco V. Green methods of lignocellulose pretreatment for biorefinery development. Appl Microbiol Biotechnol. 2016;100(22):9451-67.

3. Tang W, Wu X, Huang C, Ling Z, Lai C, Yong Q. Comprehensive understanding of the effects of metallic cations on enzymatic hydrolysis of humic acid-pretreated waste wheat straw. Biotechnol Biofuels. 2021;14(1):25

4. Zhong R, Cui D, Ye ZH. Secondary cell wall biosynthesis. N Phytol. 2019;221(4):1703-23.

5. Chen J, Fan X, Zhang L, Chen X, Sun S, Sun RC. Research progress in lignin-based slow/controlled release fertilizer. Chemsuschem. 2020;13(17):4356-66.

6. Yarbrough JM, Mittal A, Mansfield E, Taylor LE II, Hobdey SE, Sammond DW, Bomble YJ, Crowley MF, Decker SR, Himmel ME, Vinzant TB. New perspective on glycoside hydrolase binding to lignin from pretreated corn stover. Biotechnol Biofuels. 2015;8:214.

7. Sewalt VJH, Glasser WG, Beauchemin KA. Lignin impact on fiber degradation 3 reversal of inhibition of enzymatic hydrolysis by chemical modification of lignin and by additives. J Agric Food Chem. 1997;45:1823-8.

8. Rahikainen J, Mikander S, Marjamaa K, Tamminen T, Lappas A, Viikari $L$, Kruus K. Inhibition of enzymatic hydrolysis by residual lignins from softwood-study of enzyme binding and inactivation on lignin-rich surface. Biotechnol Bioeng. 2011;108(12):2823-34.

9. Liu Y, Xu J, Zhang Y, Liang C, He M, Yuan Z, Xie J. Reinforced alkali-pretreatment for enhancing enzymatic hydrolysis of sugarcane bagasse. Fuel Process Technol. 2016;143:1-6.

10. Zhang H, Wei W, Zhang J, Huang S, Xie J. Enhancing enzymatic saccharification of sugarcane bagasse by combinatorial pretreatment and Tween 80. Biotechnol Biofuels. 2018;11:309.

11. Zheng T, Jiang J, Yao J. Surfactant-promoted hydrolysis of lignocellulose for ethanol production. Fuel Process Technol. 2020;213:106660.

12. Lin X, Qiu X, Yuan L, Li Z, Lou H, Zhou M, Yang D. Lignin-based polyoxyethylene ether enhanced enzymatic hydrolysis of lignocelluloses by dispersing cellulase aggregates. Bioresour Technol. 2015;185:165-70. 
13. Akimkulova A, Zhou Y, Zhao X, Liu D. Improving the enzymatic hydrolysis of dilute acid pretreated wheat straw by metal ion blocking of non-productive cellulase adsorption on lignin. Bioresour Technol. 2016;208:110-6.

14. Halpin C. Lignin engineering to improve saccharification and digestibility in grasses. Curr Opin Biotechnol. 2019;56:223-9.

15. Masarin F, Gurpilhares DB, Baffa DC, Barbosa MH, Carvalho W, Ferraz A, Milagres AM. Chemical composition and enzymatic digestibility of sugarcane clones selected for varied lignin content. Biotechnol Biofuels. 2011;4(1):55.

16. Wang W, Zhu Y, Du J, Yang Y, Jin Y. Influence of lignin addition on the enzymatic digestibility of pretreated lignocellulosic biomasses. Bioresour Technol. 2015;181:7-12.

17. Li Y, Qi B, Luo J, Wan Y. Effect of alkali lignins with different molecular weights from alkali pretreated rice straw hydrolyzate on enzymatic hydrolysis. Bioresour Technol. 2016;200:272-8.

18. Petridis L, Smith JC. Molecular-level driving forces in lignocellulosic biomass deconstruction for bioenergy. Nat Rev Chem. 2018;2(11):382-9.

19. Vanholme R, Demedts B, Morreel K, Ralph J, Boerjan W. Lignin biosynthesis and structure. Plant Physiol. 2010;153(3):895-905.

20. Zheng Y, Yu Y, Lin W, Jin Y, Yong Q, Huang C. Enhancing the enzymatic digestibility of bamboo residues by biphasic phenoxyethanol-acid pretreatment. Bioresour Technol. 2021;325:124691.

21. Wang P, Liu C, Chang J, Yin Q, Huang W, Liu Y, Dang X, Gao T, Lu F. Effect of physicochemical pretreatments plus enzymatic hydrolysis on the composition and morphologic structure of corn straw. Renew Energy. 2019;138:502-8.

22. Wu J, Chandra RP, Kim KH, Kim CS, Pu Y, Ragauskas AJ, Saddler JN. Enhancing enzyme-mediated hydrolysis of mechanical pulps by deacetylation and delignification. ACS Sustain Chem Eng. 2020;8(15):5847-55.

23. An S, Li W, Xue F, Li X, Xia Y, Liu Q, Chen L, Jameel H, Chang HM. Effect of removing hemicellulose and lignin synchronously under mild conditions on enzymatic hydrolysis of corn stover. Fuel Process Technol. 2020;204:106407.

24. Gabhane J, Kumar S, Sarma AK. Effect of glycerol thermal and hydrothermal pretreatments on lignin degradation and enzymatic hydrolysis in paddy straw. Renew Energy. 2020;154:1304-13.

25. Chen $H$, Jiang $L$, Cheng $Y$, Lu J, LV Y, Yan J, Wang H. Improving enzymatic hydrolysis efficiency of corncob residue through sodium sulfite pretreatment. Appl Microbiol Biotechnol. 2019;103(18):7795-804.

26. Qi G, Xiong L, Tian L, Luo M, Chen X, Huang C, Li H, Chen X. Ammonium sulfite pretreatment of wheat straw for efficient enzymatic saccharification. Sustain Energy Techn. 2018;29:12-8.

27. Park N, Kim HY, Koo BW, Yeo H, Choi IG. Organosolv pretreatment with various catalysts for enhancing enzymatic hydrolysis of pitch pine (Pinus rigida). Bioresour Technol. 2010;101(18):7057-64

28. Sun S, Sun S, Cao X, Sun R. The role of pretreatment in improving the enzymatic hydrolysis of lignocellulosic materials. Bioresour Technol. 2016;199:49-58.

29. Xia Z, Li J, Zhang J, Zhang X, Zheng X, Zhang J. Processing and valorization of cellulose, lignin and lignocellulose using ionic liquids. J Bioresour Bioprod. 2020;5(2):79-95.

30. Shao J, Ni Y, Yan L. Oxidation of furfural to maleic acid and fumaric acid in deep eutectic solvent (DES) under vanadium pentoxide catalysis. J Bioresour Bioprod. 2021;6(1):39-44.

31. Brienzo M, Fikizolo S, Benjamin Y, Tyhoda L, Görgens J. Influence of pretreatment severity on structural changes, lignin content and enzymatic hydrolysis of sugarcane bagasse samples. Renew Energy. 2017;104:271-80.

32. Zhang C, Xia S, Ma P. Facile pretreatment of lignocellulosic biomass using deep eutectic solvents. Bioresour Technol. 2016;219:1-5.

33. Hao X, Li Y, Wang J, Qin Y, Zhang J. Adsorption and desorption of cellulases on/from lignin-rich residues from corn stover. Ind Crops Prod. 2019;139:111559.

34. Zhou Z, You Y, Lei F, Li P, Jiang J, Zhu L. Enhancement of enzymatic hydrolysis of sugarcane bagasse by pretreatment combined green liquor and sulfite. Fuel. 2017;203:707-14.

35. Chen F, Dixon RA. Lignin modification improves fermentable sugar yields for biofuel production. Nat Biotechnol. 2007;25(7):759-61.
36. Edmunds CW, Peralta P, Kelley SS, Chiang VL, Sharma-Shivappa RR, Davis MF, Harman-Ware AE, Sykes RW, Gjersing E, Cunningham MW, Rottmann W, Miller ZD, Peszlen I. Characterization and enzymatic hydrolysis of wood from transgenic Pinus taeda engineered with syringyl lignin or reduced lignin content. Cellulose. 2017;24(4):1901-14.

37. Davison BH, Drescher SR, Tuskan GA, Davis MF, Nghiem NP. Variation of $\mathrm{S} / \mathrm{G}$ ratio and lignin content in a Populus family influences the release of xylose by dilute acid hydrolysis. Appl Biochem Biotechnol. 2006;129-132:427-35.

38. Mansfield SD, Kang KY, Chapple C. Designed for deconstruction-poplar trees altered in cell wall lignification improve the efficacy of bioethanol production. N Phytol. 2012;194(1):91-101.

39. Wang W, Wang X, Zhang Y, Yu Q, Tan X, Zhuang X, Yuan Z. Effect of sodium hydroxide pretreatment on physicochemical changes and enzymatic hydrolysis of herbaceous and woody lignocelluloses. Ind Crops Prod. 2020;145:112145

40. Gu F, Yang L, Jin Y, Han Q, Chang HM, Jameel H, Phillips R. Green liquor pretreatment for improving enzymatic hydrolysis of corn stover. Bioresour Technol. 2012;124:299-305.

41. Haque MA, Barman DN, Kang TH, Kim MK, Kim J, Kim H, Yun HD. Effect of dilute alkali on structural features and enzymatic hydrolysis of barley straw (Hordeum vulgare) at boiling temperature with low residence time. J Microbiol Biotechnol. 2012;22(12):1681-91.

42. Wang B, Shen X, Wen J, Xiao L, Sun R. Evaluation of organosolv pretreatment on the structural characteristics of lignin polymers and follow-up enzymatic hydrolysis of the substrates from Eucalyptus wood. Int J Biol Macromol. 2017;97:447-59.

43. Sun F, Wang L, Hong J, Ren J, Du F, Hu J, Zhang Z, Zhou B. The impact of glycerol organosolv pretreatment on the chemistry and enzymatic hydrolyzability of wheat straw. Bioresour Technol. 2015;187:354-61.

44. Xu Y, Zhou Q, Li M, Bian J, Peng F. Tetrahydro-2-furanmethanol pretreatment of eucalyptus to enhance cellulose enzymatic hydrolysis and to produce high-quality lignin. Bioresour Technol. 2019;280:489-92.

45. Shen X, Wen J, Mei Q, Chen X, Sun D, Yuan T, Sun R. Facile fractionation of lignocelluloses by biomass-derived deep eutectic solvent (DES) pretreatment for cellulose enzymatic hydrolysis and lignin valorization. Green Chem. 2019;21(2):275-83.

46. Procentese A, Johnson E, Orr V, Garruto Campanile A, Wood JA, Marzocchella A, Rehmann L. Deep eutectic solvent pretreatment and subsequent saccharification of corncob. Bioresour Technol. 2015;192:31-6.

47. Ma H, Zhang B, Zhang P, Li S, Gao Y, Hu X. An efficient process for lignin extraction and enzymatic hydrolysis of corn stalk by pyrrolidonium ionic liquids. Fuel Process Technol. 2016;148:138-45.

48. Li C, Knierim B, Manisseri C, Arora R, Scheller HV, Auer M, Vogel KP, Simmons BA, Singh S. Comparison of dilute acid and ionic liquid pretreatment of switchgrass: biomass recalcitrance, delignification and enzymatic saccharification. Bioresour Technol. 2010;101(13):4900-6.

49. Poornejad N, Karimi K, Behzad T. Improvement of saccharification and ethanol production from rice straw by NMMO and [BMIM][OAC] pretreatments. Ind Crops Prod. 2013;41:408-13.

50. Tang W, Wu X, Huang C, Ling Z, Lai C, Yong Q. Revealing migration discipline of lignin during producing fermentable sugars from wheat straw through autohydrolysis. Ind Crops Prod. 2021;171:113849.

51. Takada M, Chandra RP, Saddler JN. The influence of lignin migration and relocation during steam pretreatment on the enzymatic hydrolysis of softwood and corn stover biomass substrates. Biotechnol Bioeng. 2019;116(11):2864-73.

52. Zakaria MR, Hirata S, Hassan MA. Hydrothermal pretreatment enhanced enzymatic hydrolysis and glucose production from oil palm biomass. Bioresour Technol. 2015;176:142-8.

53. Wang Z, Zhu M, Li M, Wei Q, Sun R. Effects of hydrothermal treatment on enhancing enzymatic hydrolysis of rapeseed straw. Renew Energy. 2019;134:446-52.

54. Kim JS, Lee YY, Kim TH. A review on alkaline pretreatment technology for bioconversion of lignocellulosic biomass. Bioresour Technol. 2016;199:42-8.

55. Abdul PM, Jahim JM, Harun S, Markom M, Lutpi NA, Hassan O, Balan V, Dale BE, Mohd Nor MT. Effects of changes in chemical and structural characteristic of ammonia fibre expansion (AFEX) pretreated oil palm empty fruit bunch fibre on enzymatic saccharification and fermentability for biohydrogen. Bioresour Technol. 2016;211:200-8. 
56. Zhao C, Cao Y, Ma Z, Shao Q. Optimization of liquid ammonia pretreatment conditions for maximizing sugar release from giant reed (Arundo donax L.). Biomass Bioenergy. 2017;98:61-9.

57. Zhu J, Li W, Qin L, Zhao X, Chen S, Liu H, Liu Z, Zhou X, Li X, Li B, Yuan Y. Stepwise pretreatment of aqueous ammonia and ethylenediamine improve enzymatic hydrolysis of corn stover. Ind Crops Prod. 2018;124:201-8.

58. Donaldson L, Vaidya A. Visualising recalcitrance by colocalisation of cellulase, lignin and cellulose in pretreated pine biomass using fluorescence microscopy. Sci Rep. 2017;7:44386.

59. Ko JK, Kim Y, Ximenes E, Ladisch MR. Effect of liquid hot water pretreatment severity on properties of hardwood lignin and enzymatic hydrolysis of cellulose. Biotechnol Bioeng. 2015;112(2):252-62.

60. Zhao C, Qiao X, Cao Y, Shao Q. Application of hydrogen peroxide presoaking prior to ammonia fiber expansion pretreatment of energy crops. Fuel. 2017;205:184-91.

61. Hansen MA, Kristensen JB, Felby C, Jorgensen H. Pretreatment and enzymatic hydrolysis of wheat straw (Triticum aestivum L.) the impact of lignin relocation and plant tissues on enzymatic accessibility. Bioresour Technol. 2011;102(3):2804-11.

62. Shinde SD, Meng X, Kumar R, Ragauskas AJ. Recent advances in understanding the pseudo-lignin formation in a lignocellulosic biorefinery. Green Chem. 2018;20(10):2192-205.

63. He J, Huang C, Lai C, Huang C, Li X, Yong Q. Elucidation of structureinhibition relationship of monosaccharides derived pseudo-lignin in enzymatic hydrolysis. Ind Crops Prod. 2018;113:368-75.

64. Hu F, Jung S, Ragauskas A. Impact of pseudolignin versus dilute acidpretreated lignin on enzymatic hydrolysis of cellulose. ACS Sustain Chem Eng. 2012;1(1):62-5.

65. Studer MH, DeMartini JD, Davis MF, Sykes RW, Davison B, Keller M, Tuskan GA, Wyman CE. Lignin content in natural Populus variants affects sugar release. Proc Natl Acad Sci U S A. 2011;108(15):6300-5.

66. Li X, Li M, Pu Y, Ragauskas AJ, Klett AS, Thies M, Zheng Y. Inhibitory effects of lignin on enzymatic hydrolysis: The role of lignin chemistry and molecular weight. Renew Energy. 2018;123:664-74.

67. Pu Y, Cao S, Ragauskas AJ. Application of quantitative 31P NMR in biomass lignin and biofuel precursors characterization. Energy Environ Sci. 2011:4(9):3154-66.

68. Min D, Chang HM, Jameel H, Lucia L, Wang Z, Jin Y. The structure of lignin of corn stover and its changes induced by mild sodium hydroxide treatment. BioResources. 2014;9(2):2405-14.

69. Samuel R, Pu Y, Raman B, Ragauskas AJ. Structural characterization and comparison of switchgrass ball-milled lignin before and after dilute acid pretreatment. Appl Biochem Biotechnol. 2010;162(1):62-74.

70. Papa G, Varanasi P, Sun L, Cheng G, Stavila V, Holmes B, Simmons BA, Adani F, Singh S. Exploring the effect of different plant lignin content and composition on ionic liquid pretreatment efficiency and enzymatic saccharification of Eucalyptus globulus L. mutants. Bioresour Technol. 2012;117(10):352-9

71. Xu C, Zhang J, Zhang Y, Guo Y, Xu H, Liang C, Wang Z, Xu J. Lignin prepared from different alkaline pretreated sugarcane bagasse and its effect on enzymatic hydrolysis. Int J Biol Macromol. 2019;141:484-92.

72. Tan L, Sun W, Li X, Zhao J, Qu Y, Choo YM, Loh SK. Bisulfite pretreatment changes the structure and properties of oil palm empty fruit bunch to improve enzymatic hydrolysis and bioethanol production. Biotechnol J. 2015;10(6):915-25.

73. Kim JE, Lee JW. Enzyme adsorption properties on dilute acid pretreated biomass by low vacuum-scanning electron microscopy and structural analysis of lignin. Bioresour Technol. 2018;262:107-13.

74. Ko JK, Ximenes E, Kim Y, Ladisch MR. Adsorption of enzyme onto lignins of liquid hot water pretreated hardwoods. Biotechnol Bioeng. 2015;112(3):447-56.

75. Nakagame S, Chandra RP, Saddler JN. The effect of isolated lignins, obtained from a range of pretreated lignocellulosic substrates, on enzymatic hydrolysis. Biotechnol Bioeng. 2010;105(5):871-9.

76. Li X, Ximenes E, Kim Y, Slininger M, Meilan R, Ladisch M, Chapple C. Lignin monomer composition affects Arabidopsis cell-wall degradability after liquid hot water pretreatment. Biotechnol Biofuels. 2010;3(1):27.

77. Ko JK, Um Y, Park YC, Seo JH, Kim KH. Compounds inhibiting the bioconversion of hydrothermally pretreated lignocellulose. Appl Microbiol Biotechnol. 2015;99(10):4201-12.
78. Zhao C, Qiao X, Shao Q, Hassan M, Ma Z. Evolution of the lignin chemical structure during the bioethanol production process and its inhibition to enzymatic hydrolysis. Energy Fuels. 2020;34(5):5938-47.

79. Fu C, Mielenz JR, Xiao X, Ge Y, Hamilton CY, Rodriguez M Jr, Chen F, Foston M, Ragauskas A, Bouton J, Dixon RA, Wang ZY. Genetic manipulation of lignin reduces recalcitrance and improves ethanol production from switchgrass. Proc Natl Acad Sci U S A. 2011:108(9):3803-8.

80. Bonawitz ND, Kim J, Tobimatsu Y, Ciesielski PN, Anderson NA, Ximenes E, Maeda J, Ralph J, Donohoe BS, Ladisch M, Chapple C. Disruption of Mediator rescues the stunted growth of a lignin-deficient Arabidopsis mutant. Nature. 2014;509(7500):376-80.

81. Azarpira A, Lu F, Ralph J. Reactions of dehydrodiferulates with ammonia. Org Biomol Chem. 2011;9(19):6779-87.

82. Kothari N, Bhagia S, Pu Y, Yoo CG, Li M, Venketachalam S, Pattathil S, Kumar R, Cai CM, Hahn MG, Ragauskas AJ, Wyman CE. The effect of switchgrass plant cell wall properties on its deconstruction by thermochemical pretreatments coupled with fungal enzymatic hydrolysis or Clostridium thermocellum consolidated bioprocessing. Green Chem. 2020;22(22):7924-45.

83. Reinoso FAM, Rencoret J, Gutierrez A, Milagres AMF, Del Rio JC, Ferraz A Fate of $p$-hydroxycinnamates and structural characteristics of residual hemicelluloses and lignin during alkaline-sulfite chemithermomechanical pretreatment of sugarcane bagasse. Biotechnol Biofuels. 2018:11:153.

84. Yoo CG, Kim H, Lu F, Azarpira A, Pan X, Oh KK, Kim JS, Ralph J, Kim TH. Understanding the physicochemical characteristics and the improved enzymatic saccharification of corn stover pretreated with aqueous and gaseous ammonia. BioEnergy Res. 2016;9(1):67-76.

85. Murciano Martinez P, Punt AM, Kabel MA, Gruppen H. Deconstruction of lignin linked p-coumarates, ferulates and xylan by $\mathrm{NaOH}$ enhances the enzymatic conversion of glucan. Bioresour Technol. 2016;216:44-51.

86. Samuel R, Cao S, Das BK, Hu F, Pu Y, Ragauskas AJ. Investigation of the fate of poplar lignin during autohydrolysis pretreatment to understand the biomass recalcitrance. RSC Adv. 2013;3(16):5305-9.

87. Lai C, Yang B, Lin Z, Jia Y, Huang C, Li X, Song X, Yong Q. New strategy to elucidate the positive effects of extractable lignin on enzymatic hydrolysis by quartz crystal microbalance with dissipation. Biotechnol Biofuels. 2019;12:57.

88. Jeong SY, Lee EJ, Ban SE, Lee JW. Structural characterization of the lignin-carbohydrate complex in biomass pretreated with Fenton oxidation and hydrothermal treatment and consequences on enzymatic hydrolysis efficiency. Carbohydr Polym. 2021;270:118375.

89. Yoo CG, Li M, Meng X, Pu Y, Ragauskas AJ. Effects of organosolv and ammonia pretreatments on lignin properties and its inhibition for enzymatic hydrolysis. Green Chem. 2017;19(8):2006-16.

90. Huang C, He J, Min D, Lai C, Yong Q. Understanding the nonproductive enzyme adsorption and physicochemical properties of residual lignins in Moso Bamboo pretreated with sulfuric acid and kraft pulping. Appl Biochem Biotechnol. 2016;180(8):1508-23.

91. Song Y, Chandra RP, Zhang X, Saddler JN. Non-productive celluase binding onto deep eutectic solvent (DES) extracted lignin from willow and corn stover with inhibitory effects on enzymatic hydrolysis of cellulose. Carbohydr Polym. 2020;250:116956.

92. Tarasov D, Leitch M, Fatehi P. Lignin-carbohydrate complexes: properties, applications, analyses, and methods of extraction: a review. Biotechnol Biofuels. 2018;11:269.

93. Min D, Yang C, Chiang V, Jameel H, Chang HM. The influence of lignincarbohydrate complexes on the cellulase-mediated saccharification II: transgenic hybrid poplars (Populus nigra L. and Populus maximowiczii A.). Fuel. 2014;116:56-62.

94. Singh S, Cheng G, Sathitsuksanoh N, Wu D, Varanasi P, George A, Balan V, Gao X, Kumar R, Dale BE, Wyman CE, Simmons BA. Comparison of different biomass pretreatment techniques and their impact on chemistry and structure. Front Energy Res. 2015;2:62.

95. Li H, Wang B, Wen J, Cao X, Sun S, Sun R. Availability of four energy crops assessing by the enzymatic hydrolysis and structural features of lignin before and after hydrothermal treatment. Energy Convers Manage. 2018;155:58-67.

96. Yu Z, Gwak KS, Treasure T, Jameel H, Chang HM, Park S. Effect of lignin chemistry on the enzymatic hydrolysis of woody biomass. Chemsuschem. 2014;7(7):1942-50. 
97. Xu C, Liu F, Alam MA, Chen H, Zhang Y, Liang C, Xu H, Huang S, Xu J, Wang Z. Comparative study on the properties of lignin isolated from different pretreated sugarcane bagasse and its inhibitory effects on enzymatic hydrolysis. Int J Biol Macromol. 2020;146:132-40.

98. Yang Q, Pan X. Correlation between lignin physicochemical properties and inhibition to enzymatic hydrolysis of cellulose. Biotechnol Bioeng. 2016:113(6):1213-24.

99. Ying $W$, Shi Z, Yang H, Xu G, Zheng Z, Yang J. Effect of alkaline lignin modification on cellulase-lignin interactions and enzymatic saccharification yield. Biotechnol Biofuels. 2018;11:214.

100. Guo F, Shi W, Sun W, Li X, Wang F, Zhao J, Qu Y. Differences in the adsorption of enzymes onto lignins from diverse types of lignocellulosic biomass and the underlying mechanism. Biotechnol Biofuels. 2014;7(1):38.

101. Pan XJ. Role of functional groups in lignin inhibition of enzymatic hydrolysis of cellulose to glucose. J Biobased Mater Bioenergy. 2008;2(1):25-32.

102. Qin L, Li W, Liu L, Zhu J, Li X, Li B, Yuan Y. Inhibition of lignin-derived phenolic compounds to cellulase. Biotechnol Biofuels. 2016;9:70.

103. Zhang H, Wu S, Xie J. Evaluation of the effects of isolated lignin on enzymatic hydrolysis of cellulose. Enzyme Microb Technol. 2017;101:44-50.

104. Lai C, Tu M, Shi Z, Zheng K, Olmos LG, Yu S. Contrasting effects of hardwood and softwood organosolv lignins on enzymatic hydrolysis of lignocellulose. Bioresour Technol. 2014;163:320-7.

105. Lai C, Tu M, Li M, Yu S. Remarkable solvent and extractable lignin effects on enzymatic digestibility of organosolv pretreated hardwood. Bioresour Technol. 2014;156:92-9.

106. Nakagame S, Chandra RP, Kadla JF, Saddler JN. Enhancing the enzymatic hydrolysis of lignocellulosic biomass by increasing the carboxylic acid content of the associated lignin. Biotechnol Bioeng. 2011;108(3):538-48

107. Jia L, Qin Y, Wang J, Zhang J. Lignin extracted by gamma-valerolactone/ water from corn stover improves cellulose enzymatic hydrolysis. Bioresour Technol. 2020;302:122901.

108. Hassanpour M, Abbasabadi M, Gebbie L, Te'o VSJ, O'Hara IM, Zhang Z. Acid-catalyzed glycerol pretreatment of sugarcane bagasse: understanding the properties of lignin and its effects on enzymatic hydrolysis. ACS Sustain Chem Eng. 2020;8(28):10380-8.

109. Lan TQ, Wang SR, Li H, Qin YY, Yue GJ. Effect of lignin isolated from p-toluenesulfonic acid pretreatment liquid of sugarcane bagasse on enzymatic hydrolysis of cellulose and cellulase adsorption. Ind Crops Prod. 2020;155:112768.

110. Wang W, Zhuang X, Yuan Z, Qi W, Yu Q, Wang Q. Structural changes of lignin after liquid hot water pretreatment and its effect on the enzymatic hydrolysis. BioMed Res Int. 2016;2016:1-7.

111. Sheng Y, Lam SS, Wu Y, Ge S, Wu J, Cai L, Huang Z, Le QV, Sonne C, Xia C. Enzymatic conversion of pretreated lignocellulosic biomass: a review on influence of structural changes of lignin. Bioresour Technol. 2021;324:124631.

112. Pielhop T, Larrazábal GO, Rudolf von Rohr P. Autohydrolysis pretreatment of softwood-enhancement by phenolic additives and the effects of other compounds. Green Chem. 2016;18(19):5239-47.

113. Lai C, Tu M, Yong Q, Yu S. Disparate roles of solvent extractable lignin and residual bulk lignin in enzymatic hydrolysis of pretreated sweetgum. RSC Adv. 2015:5(119):97966-74.

114. Nakagame S, Chandra RP, Saddler JN, Zhu J, Zhang X, Pan X. The influence of lignin on the enzymatic hydrolysis of pretreated biomass substrates. Acs Symp. 2011;1067:145-67.

115. Lai C, Tu M, Yong Q, Yu S. Synergistic effects of $\mathrm{pH}$ and organosolv lignin addition on the enzymatic hydrolysis of organosolv-pretreated loblolly pine. RSC Adv. 2018;8(25):13835-41.

116. Wang J, Hao X, Wen P, Zhang T, Zhang J. Adsorption and desorption of cellulase on/from lignin pretreated by dilute acid with different severities. Ind Crops Prod. 2020:148:11230.

117. Rahikainen JL, Martinsampedro R, Heikkinen H, Rovio S, Marjamaa K, Tamminen T, Rojas OJ, Kruus K. Inhibitory effect of lignin during cellulose bioconversion: the effect of lignin chemistry on non-productive enzyme adsorption. Bioresour Technol. 2013;133(2):270-8.

118. Kellock M, Rahikainen J, Marjamaa K, Kruus K. Lignin-derived inhibition of monocomponent cellulases and a xylanase in the hydrolysis of lignocellulosics. Bioresour Technol. 2017;232:183-91.
119. Wang Z, Lan T, Zhu J. Lignosulfonate and elevated pH can enhance enzymatic saccharification of lignocelluloses. Biotechnol Biofuels. 2013;6(1):9.

120. Zhu Y, Wang W, Wang Y, Jin Y. Effects of $\mathrm{pH}$ and sulfonated lignin on the enzymatic saccharification of acid bisulfite- and green liquor-pretreated poplar wood. BioResources. 2015;10(4):7361-71.

121. Zhou H, Lou H, Yang D, Zhu J, Qiu X. Lignosulfonate to enhance enzymatic saccharification of lignocelluloses: role of molecular weight and substrate lignin. Ind Eng Chem Res. 2013;52(25):8464-70.

122. Jiang B, Yu J, Luo X, Zhu Y, Jin Y. A strategy to improve enzymatic saccharification of wheat straw by adding water-soluble lignin prepared from alkali pretreatment spent liquor. Process Biochem. 2018:71:147-51.

123. Lou H, Wang M, Lai H, Lin X, Zhou M, Yang D, Qiu X. Reducing nonproductive adsorption of cellulase and enhancing enzymatic hydrolysis of lignocelluloses by noncovalent modification of lignin with lignosulfonate. Bioresour Technol. 2013;146:478-84.

124. Lin X, Wu L, Huang S, Qin Y, Qiu X, Lou H. Effect of lignin-based amphiphilic polymers on the cellulase adsorption and enzymatic hydrolysis kinetics of cellulose. Carbohydr Polym. 2019;207:52-8.

125. Zhan X, Cai C, Pang Y, Qin F, Lou H, Huang J, Qiu X. Effect of the isoelectric point of $\mathrm{pH}$-responsive lignin-based amphoteric surfactant on the enzymatic hydrolysis of lignocellulose. Bioresour Technol. 2019:283:112-9.

126. Kumar L, Chandra R, Saddler J. Influence of steam pretreatment severity on post-treatments used to enhance the enzymatic hydrolysis of pretreated softwoods at low enzyme loadings. Biotechnol Bioeng. 2011;108(10):2300-11.

127. Wang G, Pan X, Zhu J, Gleisner R, Rockwood D. Sulfite pretreatment to overcome recalcitrance of lignocellulose (SPORL) for robust enzymatic saccharification of hardwoods. Biotechnol Progr. 2009:25(4):1086-93.

128. Zhu J, Pan X, Wang G, Gleisner R. Sulfite pretreatment (SPORL) for robust enzymatic saccharification of spruce and red pine. Bioresour Technol. 2009;100(8):2411-8.

129. Lou H, Zhou H, Li X, Wang M, Zhu J, Qiu X. Understanding the effects of lignosulfonate on enzymatic saccharification of pure cellulose. Cellulose. 2014;21(3):1351-9.

130. Wang Z, Zhu J, Fu Y, Qin M, Shao Z, Jiang J, Yang F. Lignosulfonatemediated cellulase adsorption: enhanced enzymatic saccharification of lignocellulose through weakening nonproductive binding to lignin. Biotechnol Biofuels. 2013;6(1):156.

131. Saini JK, Patel AK, Adsul M, Singhania RR. Cellulase adsorption on lignin: a roadblock for economic hydrolysis of biomass. Renew Energy 2016;98:29-42.

132. Vermaas JV, Petridis L, Qi X, Schulz R, Lindner B, Smith JC. Mechanism of lignin inhibition of enzymatic biomass deconstruction. Biotechnol Biofuels. 2015:8:217

133. Djajadi DT, Jensen MM, Oliveira M, Jensen A, Thygesen LG, Pinelo M, Glasius M, Jorgensen H, Meyer AS. Lignin from hydrothermally pretreated grass biomass retards enzymatic cellulose degradation by acting as a physical barrier rather than by inducing nonproductive adsorption of enzymes. Biotechnol Biofuels. 2018;11:85.

134. Li H, Pu Y, Kumar R, Ragauskas AJ, Wyman CE. Investigation of lignin deposition on cellulose during hydrothermal pretreatment, its effect on cellulose hydrolysis, and underlying mechanisms. Biotechnol Bioeng. 2014;111(3):485-92

135. Selig MJ, Viamajala S, Decker SR, Tucker MP, Himmel ME, Vinzant TB, Deposition of lignin droplets produced during dilute acid pretreatment of maize stems retards enzymatic hydrolysis of cellulose. Biotechnol Progr. 2007;23(6):1333-9.

136. Donaldson LA, Wong KKY, Mackie KL. Rotorua. Ultrastructure of steamexploded wood. Wood Sci Technol. 1988;22:103-14.

137. Martin-Sampedro R, Rahikainen JL, Johansson LS, Marjamaa K, Laine J, Kruus K, Rojas OJ. Preferential adsorption and activity of monocomponent cellulases on lignocellulose thin films with varying lignin content. Biomacromol. 2013;14(4):1231-9.

138. Qin C, Clarke K, Li K. Interactive forces between lignin and cellulase as determined by atomic force microscopy. Biotechnol Biofuels. 2014;7:65.

139. Yoo CG, Meng X, Pu Y, Ragauskas AJ. The critical role of lignin in lignocellulosic biomass conversion and recent pretreatment strategies: a comprehensive review. Bioresour Technol. 2020:301:12278. 
140. Palonen H, Tjerneld F, Zacchi G, Tenkanen M. Adsorption of Trichoderma reesei $\mathrm{CBH}$ I and EG II and their catalytic domains on steam pretreated softwood and isolated lignin. J Biotechnol. 2004;107(1):65-72.

141. Le Costaouec T, Pakarinen A, Varnai A, Puranen T, Viikari L. The role of carbohydrate binding module (CBM) at high substrate consistency: comparison of Trichoderma reesei and Thermoascus aurantiacus Cel7A (CBHI) and Cel5A (EGII). Bioresour Technol. 2013;143:196-203.

142. Lu X, Zheng X, Li X, Zhao J. Adsorption and mechanism of cellulase enzymes onto lignin isolated from corn stover pretreated with liquid hot water. Biotechnol Biofuels. 2016;9(1):118.

143. Notley SM, Norgren M. Surface energy and wettability of spin-coated thin films of lignin isolated from wood. Langmuir. 2010;26(8):5484-90.

144. Eriksson M, Notley SM, Wagberg L. Cellulose thin films: degree of cellulose ordering and its influence on adhesion. Biomacromol. 2007:8(3):912-9

145. Norgren M, Gardlund L, Notley SM, Htun M, Wagberg L. Smooth model surfaces from lignin derivatives. II. Adsorption of polyelectrolytes and PECs monitored by QCM-D. Langmuir. 2007;23(7):3737-43.

146. Berlin A, Balakshin M, Gilkes N, Kadla J, Maximenko V, Kubo S, Saddler J. Inhibition of cellulase, xylanase and beta-glucosidase activities by softwood lignin preparations. J Biotechnol. 2006;125(2):198-209.

147. Baig KS, Turcotte G. Adsorption of cellulose enzymes on lignocellulosic materials and influencing factors: a review. Int J Waste Resour. 2016;6:3.

148. Lou H, Zhu JY, Lan TQ, Lai H, Qiu X. pH-induced lignin surface modification to reduce nonspecific cellulase binding and enhance enzymatic saccharification of lignocelluloses. Chemsuschem. 2013;6(5):919-27.

149. Sewalt VJH, Glasser WG, Beauchemin KA. Lignin impact on fiber degradation. 3. Reversal of inhibition of enzymatic hydrolysis by chemical modification of lignin and by additives. J Agric Food Chem. 1997:45(5):1823-8.

150. Zhang $Y, X u X$, Zhang Y, Li J. Effect of adding surfactant for transforming lignocellulose into fermentable sugars during biocatalysing. Biotechnol Bioprocess Eng. 2011;16(5):930-6.

151. Stamogiannou I, Van Camp J, Smagghe G, Van de Walle D, Dewettinck K, Raes K. Impact of phenolic compound as activators or inhibitors on the enzymatic hydrolysis of cellulose. Int J Biol Macromol. 2021;186:174-80

152. Dos Santos AC, Ximenes E, Kim Y, Ladisch MR. Lignin-enzyme interactions in the hydrolysis of lignocellulosic biomass. Trends Biotechnol. 2019;37(5):518-31.

153. Ximenes E, Kim Y, Mosier N, Dien B, Ladisch M. Deactivation of cellulases by phenols. Enzyme Microb Technol. 2011:48(1):54-60.

154. Kim Y, Ximenes E, Mosier NS, Ladisch MR. Soluble inhibitors/deactivators of cellulase enzymes from lignocellulosic biomass. Enzyme Microb Technol. 2011:48(4-5):408-15.

155. Kim Y, Kreke T, Hendrickson R, Parenti J, Ladisch MR. Fractionation of cellulase and fermentation inhibitors from steam pretreated mixed hardwood. Bioresour Technol. 2013;135:30-8

156. Ximenes E, Kim Y, Mosier N, Dien B, Ladisch M. Inhibition of cellulases by phenols. Enzyme Microb Technol. 2010;46(3-4):170-6.

157. Peciulyte A, Samuelsson L, Olsson L, McFarland KC, Frickmann J, Ostergard L, Halvorsen R, Scott BR, Johansen KS. Redox processes acidify and decarboxylate steam-pretreated lignocellulosic biomass and are modulated by LPMO and catalase. Biotechnol Biofuels. 2018;11:165.
158. Jonsson LJ, Martin C. Pretreatment of lignocellulose: formation of inhibitory by-products and strategies for minimizing their effects. Bioresour Technol. 2016;199:103-12.

159. Mattison KW, Dubin PL, Brittain IJ. Complex formation between bovine serum albumin and strong polyelectrolytes: effect of polymer charge density. J Phys Chem B. 1998;102(19):3830-6.

160. Zheng W, Lan T, Li H, Yue G, Zhou H. Exploring why sodium lignosulfonate influenced enzymatic hydrolysis efficiency of cellulose from the perspective of substrate-enzyme adsorption. Biotechnol Biofuels. 2020;13:19.

161. Leu SY, Zhu JY. Substrate-related factors affecting enzymatic saccharification of lignocelluloses: our recent understanding. BioEnergy Res. 2012;6(2):405-15.

162. Lin X, Qiu X, Lou H, Li Z, Zhan N, Huang J, Pang Y. Enhancement of lignosulfonate-based polyoxyethylene ether on enzymatic hydrolysis of lignocelluloses. Ind Crops Prod. 2016;80:86-92.

163. Liu H, Zhu J, Fu S. Effects of lignin-metal complexation on enzymatic hydrolysis of cellulose. J Agric Food Chem. 2010:58(12):7233-8.

164. He J, Huang C, Lai C, Jin Y, Ragauskas A, Yong Q. Investigation of the effect of lignin/pseudo-lignin on enzymatic hydrolysis by Quartz Crystal Microbalance. Ind Crops Prod. 2020;157:112927.

165. Jiang C, Cao T, Wu W, Song J, Jin Y. Novel approach to prepare ultrathin lignocellulosic film for monitoring enzymatic hydrolysis process by Quartz Crystal Microbalance. ACS Sustain Chem Eng. 2017;5(5):3837-44.

166. Zhao X, Meng X, Ragauskas AJ, Lai C, Ling Z, Huang C, Yong Q. Unlocking the secret of lignin-enzyme interactions: Recent advances in developing state-of-the-art analytical techniques. Biotechnol Adv. 2021. https://doi.org/10.1016/j.biotechadv.2021.107830.

167. Lin W, Yang J, Zheng Y, Huang C, Yong Q. Understanding the effects of different residual lignin fractions in acid-pretreated bamboo residues on its enzymatic digestibility. Biotechnol Biofuels. 2021;14(1):143.

168. Pereira A, Hoeger IC, Ferrer A, Rencoret J, Del Rio JC, Kruus K, Rahikainen J, Kellock M, Gutierrez A, Rojas OJ. Lignin films from spruce, eucalyptus, and wheat straw studied with electroacoustic and optical sensors: effect of composition and electrostatic screening on enzyme binding. Biomacromol. 2017;18(4):1322-32.

169. Yamamoto Y, Cheng N, Koda K, Igarashi K, Tamai Y, Uraki Y. Association of amphipathic lignin derivatives with cellobiohydrolase groups improves enzymatic saccharification of lignocellulosics. Cellulose. 2017;24(4):1849-62.

170. Arslan B, Egerton K, Zhang X, Abu-Lail NI. Effects of the surface morphology and conformations of lignocellulosic biomass biopolymers on their nanoscale interactions with hydrophobic self-assembled monolayers. Langmuir. 2017;33(27):6857-68.

171. Arslan B, Colpan M, Ju X, Zhang X, Kostyukova A, Abu-Lail NI. The effects of noncellulosic compounds on the nanoscale interaction forces measured between carbohydrate-binding module and lignocellulosic biomass. Biomacromol. 2016;17(5):1705-15.

\section{Publisher's Note}

Springer Nature remains neutral with regard to jurisdictional claims in published maps and institutional affiliations. 